Chapter 5

\title{
Biodegradation of Melanoidin from Distillery Effluent: Role of Microbes and Their Potential Enzymes
}

\author{
Anita Rani Santal and Nater Pal Singh \\ Additional information is available at the end of the chapter \\ http://dx.doi.org/10.5772/56252
}

\section{Introduction}

Bioremediation is the process that deals with the microbial degradation of hazardous compounds from environment. The process of bioremediation is the natural process of biodegradation, which can degrade the pollutants and sometimes can completely oxidize the compound. Microorganisms play the vital role in the process of bioremediation and biodegradation because of their great metabolic diversity, which includes the ability to metabolise these pollutants [1]. The degradation of toxic compounds to less harmful forms with the use of biological systems is called as bioremediation [2]. Bioremediation is limited in the number of toxic material, it can handle but where applicable it is cost effective and ecofriendly [3]. Today, water resources have been the most exploited of the natural systems, most of our water bodies are seriously polluted due to rapid population growth, industrial proliferation, urbanizations, increasing living standards and wide spheres of human activities. Many rivers of the world receive heavy flux due to industrial effluents [4]. The wastewater consisting of substances varying from simple nutrients to highly toxic hazardous chemicals, which when used for irrigation caused both beneficial and damaging effects to various crops including vegetables [5].

The awful consequence of increasing population along with an rapidly increase in the industrial field is a major concern of pollution in the environment. Water is necessary for irrigation to increase the productivity in agriculture. Industrial effluents already pollute most of the Indian rivers. Many industries are playing the crucial role in water pollution such as textile industries, dairy industries and distillery etc. Distilleries are the major agro-based industries, which utilize molasses as raw material for the production of rectified spirit. In addition to rectified spirit, distilleries also produce ethanol, which can be mixed with diesel and used as biofuel and helps in reducing import of crude oil thereby saving foreign exchange 
[6]. In the year 1999, there were 285 distilleries in India producing $2.70 \times 10^{9} \mathrm{~L}$ of wastewater each year [7]. This number has gone up to 319 producing $3.25 \times 10^{9} \mathrm{~L}$ of alcohol and generating $4.04 \times 10^{11} \mathrm{~L}$ of wastewater annually [8] and this effluent or spent wash is a major source of aquatic and soil pollution [9]. The spentwash is highly acidic in nature and has a variety of recalcitrant coloring compounds as melanoidins, phenolics and metal sulfides that are mainly responsible for the dark color of distillery effluent. The $\mathrm{pH}$ of spentwash increases from 4.5 to 8.5 during the anaerobic treatment process and finally it is called as post methanated distillery effluent (PMDE). The spentwash is a waste having very high biochemical oxygen demand (BOD; 35,000-40,000 $\mathrm{mgL}^{-1}$ ), chemical oxygen demand (COD; 90,000-1,10,000 $\mathrm{mgL}^{-1}$ ), total solids (TS; $\left.82,480 \mathrm{mgL}^{-1}\right)$, nitrogen $\left(2,200 \mathrm{mgL}^{-1}\right)$, phenolics $\left(4.20 \mathrm{mgL}^{-1}\right)$ and sulphate $(3,410$ $\left.\mathrm{mgL}^{-1}\right)$. In addition to these contaminants, several heavy metals ( $\mathrm{Cd}, \mathrm{Mn}, \mathrm{Fe}, \mathrm{Zn}, \mathrm{Ni}$ and $\mathrm{Pb}$ ) are also present. The spentwash primarily undergoes anaerobic treatment process which converts a significant proportion $(>50 \%)$ of the BOD and COD. However, different biochemical changes in the spentwash occur during anaerobic digestion. There is formation of significant amount of hydrogen sulfide $\left(\mathrm{H}_{2} \mathrm{~S}\right)$ as a result of the reduction of oxidized sulfur compound. Sulfide binds with the heavy metals present in the effluent and forms a colloidal solution of metal sulfide colorant [10]. This massive quantity, approx. 40 billion litres of effluent, if disposed untreated can cause considerable stress on the watercourses leading to widespread damage to aquatic life. Moreover, the oxygen is also exhausted giving death of fishes and other aquatic life. This wastewater is extremely harmful to the plants. Cane molasses contained around $2 \%$ of dark brown pigment melanoidins [11]. Dark brown color hinders photosynthesis by blocking sunlight and is therefore deleterious to aquatic life [12-14]. It reduces soil alkalinity and inhibits seed germination. Further due to the possibility of complexation reaction of introduced melanoidins with metal ions, they could influence the biogeochemical cycle of many constituents in natural water [14], which are highly resistant to microbial attack. Hence, the wastewater requires pretreatment before its safe disposal into the environment $[15,16]$.

This book chapter contributes and summarizes the literature available on the structure, nature and properties of melanoidins. Besides these, the important part of this chapter involves role of bacteria, fungi, yeast and algae helps in biodegradation of melanoidins and also the enzymes involved in the degradation of melanoidins. Therefore, this chapter has a major significance in the prevention of environmental pollution.

\section{Nature of melanoidins}

Melanoidins are natural, dark brown, complex biopolymers produced by non-enzymatic browning reactions called as Maillard amino-carbonyl reaction taking place between the amino and carbonyl groups in organic substances [17, 18]. It is considered that melanoidins extensively exist in food, drinks and wastewater released from distillery and fermentation industries. Melanoidins exist not only in various foods but also in various industrial wastes e.g. distillery and sugar mill wastes [16]. Melanoidins owing to their structural complexity, dark color and offensive odour pose threat to aquatic and terrestrial ecosystem. Currently, the most visible environmental problem caused by contamination with melanoidin compounds 
is eutrophication in natural water bodies, reduction of sunlight penetration leading to decreased photosynthetic activity and dissolved oxygen concentration in lakes, rivers or lagoons $[19,20]$. Therefore, the degradation and decolorization of molasses melanoidin by chemical [21] and biological means [20,22] has been attempted in order to characterize the chemical structure and bioremediation aspects.

Melanoidins are generated through the maillard reaction. Maillard reaction is known to proceed non-enzymatically between amino and carbonyl groups of organic matter $[13,14,17$, 18,23 ] and are closely related to humic substances in the natural environment [24]. There are two important pathways in the non-enzymatic browning of food i.e. caramelization and maillard reaction. That leads to the formation of volatile aromatic compounds, intermediate nonvolatile compounds, and brown pigments called melanoidins. Since they are highly resistant to microbial attack, the conventional biological processes are inapplicable to color removal from melanoidin containing wastewater from distillery [13].

Melanoidins have physiologically positive effects such as anti-oxidative activity including strong scavenging activity against reactive oxygen species [13, 25]. Miyata et al. [26] in their studies attempt to utilize the strong oxidizing activity of a white rot fungus Coriolus hirsutus to decolorise melanoidins, which is a main color component of heat treatment liquor of sewage sludge. This reaction occurs in many situations, in foods [27], in vivo, and in soil. Melanoidins, which are the final by-products of the reaction, are brown nitrogen containing polymers that are difficult to decompose. The formation of melanoidins is affected by the reactants and their concentrations, types of catalysts and buffers, reaction temperature, time, $\mathrm{pH}$ value, water activity, presence of oxygen and metal ions. During heat treatment, the maillard reaction accompanied by formation of a class of compounds known as maillard products. The reaction proceeds effectively $>50{ }^{\circ} \mathrm{C}$ and is favoured at $\mathrm{pH} 4$ to 7 [28]. Recently, the empirical formula of melanoidins has been suggested as $\mathrm{C}_{17-18} \mathrm{H}_{26-27} \mathrm{O}_{10} \mathrm{~N}$ [13]. The basic structure of melanoidin is given in Figure 1 [29]. The molecular weight distribution is between 5-40 kDa. It consists of acidic, polymeric and highly dispersed colloids, which are negatively charged due to the dissociation of carboxylic acids and phenoilc groups [30]. Due to their antioxidant properties, melanoidins are toxic to many microorganisms involved in wastewater treatment [31]. Melanoidins and their degradation are generally recalcitrant to biodegradation due to their complex structure and xenobiotic nature and in some cases are both mutagenic and carcinogenic [14]. Melanoidins behave as anionic hydrophilic polymers, which can form stable complexes with metal cations and reported that ketone or hydroxyl groups of pyranone or pyridone residues act as donor groups in melanoidins and participate in the chelation with metals as melanoidins have net negative charge and therefore, different heavy metals $\left(\mathrm{Cu}^{2+}\right.$, $\mathrm{Cr}^{3+}, \mathrm{Fe}^{3+}, \mathrm{Zn}^{2+}, \mathrm{Pb}^{2+}$, etc.) form large complex molecules with melanoidins, amino acids, proteins and sugars in acidic medium and get precipitated [14, 32].

Miura et al. [33] have reported the formation of colored compounds formed in the maillard reaction between $\mathrm{D}$-xylose and glycine. These pigments turned brown with decomposition, so they had been postulated to be important intermediates in the generation of melanoidins. Hayase et al. [34] have reported the identification of the novel blue pigment designated as BlueM1. These consist of four molecules of D-xylose and glycine, and also have methine proton 


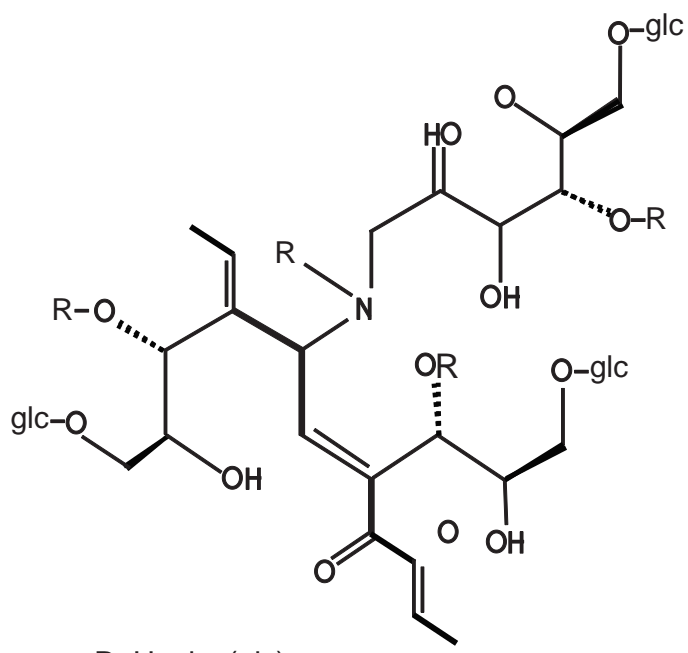

$\mathrm{R}: \mathrm{H}$; glc: (glc)

Figure 1. Basic structure of melanoidins [29].

between two pyrrolpyrrole rings. In the initial stage of maillard reaction, disaccharides form a Schiff base with amino groups of amino acids and are subsequently transformed via the Amadori rearrangement product $[35,36]$.

\section{Degradation of melanoidin polymer}

Waste treatment methods aim the removal of unwanted compounds in wastewater for safe discharge into environment. Various technologies have been used for reducing the pollution load from distillery wastewater, which included physico-chemical treatment (Adsorption, Coagulation and flocculation, Oxidation process, Membrane treatment, Evaporation/combustion) and biological treatment (Figure 2) [37].

Adsorption techniques for wastewater treatment have become more popular in recent years. Among the physico-chemical processes, adsorption technology is considered to be one the most effective and proven technology having potential application in both water and wastewater treatment. Adsorption is a rapid phenomenon of passive sequestration and separation of adsorbate from aqueous/gaseous phase on to solid phase [38]. Decolorization of synthetic melanoidin using commercially available activated carbon as well as activated carbon produced from sugarcane bagasse was investigated by Bernardo et al. [39]. Activated carbon is a well known adsorbent due to its extended surface area, microporous structure, high adsorption capacity and high degree of surface reactivity. Previous studies on decolorization of molasses wastewater include adsorption on commercial as well as indigenously prepared activated carbons [40]. Coagulation involves the destabilization of colloidal particles (e.g. 


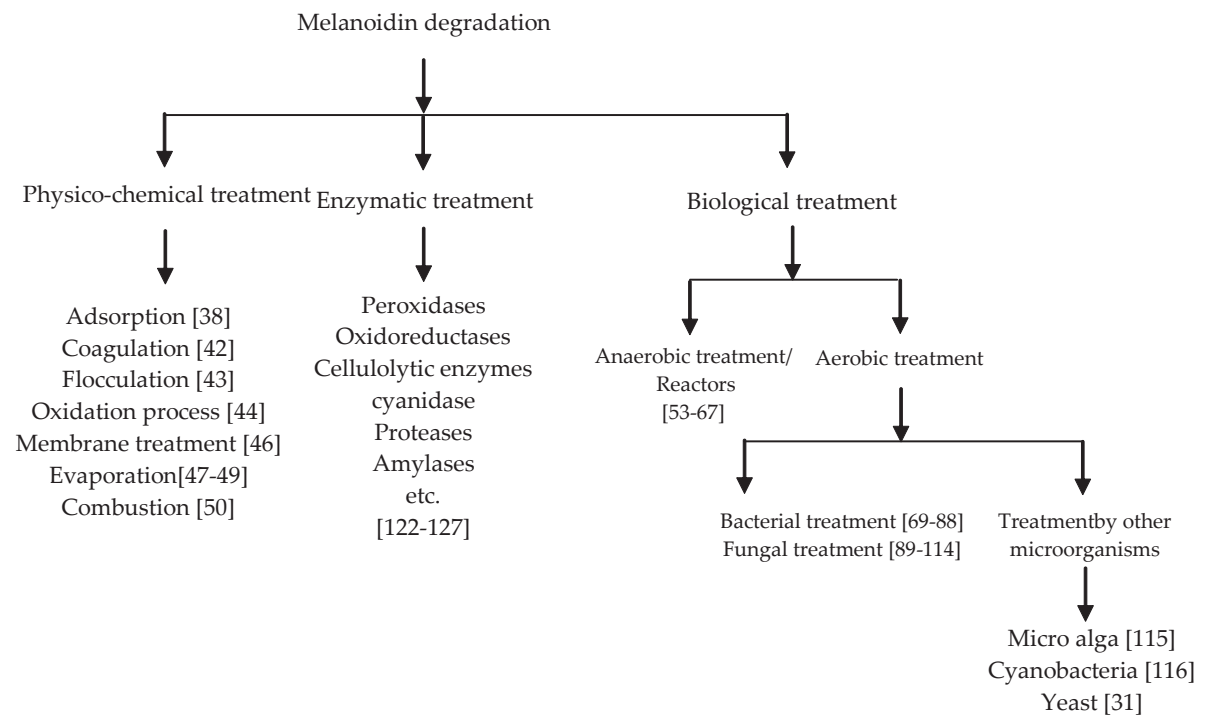

Figure 2. Various methods of melanoidin degradation.

mineral colloids, microbial cells, virus particles) and sometimes by coagulant aids (e.g. activated silica, bentonite, polyelectrolytes, starch) [41]. Coagulation of the wastewater containing recalcitrant pollutants is practiced through use of conventional salts of aluminium and iron as coagulants [42]. Migo et al. [43] used a commercial inorganic flocculent, a polymer of ferric hydroxysulfate with a chemical formula $\left[\mathrm{Fe}_{2}(\mathrm{OH})_{\mathrm{n}}(\mathrm{SO} 4)_{3-\mathrm{n} / 2}\right]_{\mathrm{m}}$ for the treatment of molasses wastewater.

A study comparing the efficiency in decolorising biologically pretreated molasses wastewater of different oxidation processes using ozone, single hydrogen peroxide, Fenton's reagent and ozone combined with hydrogen peroxide has been performed. Ozone treatment was able to reduce about $76 \%$ of color. A combination of ozone with a low concentration of hydrogen peroxide was able to increase the color removal efficiency up to $89 \%$. Gel permeation chromatography corroborated the reduction in the concentration of chromophore groups responsible for wastewater color. Single hydrogen peroxide and Fenton's reagent were not able to reduce the color. Bicarbonate ions were found to be strong inhibitors of decolorising reactions [44]. Kumaresan et al. [45] employed emulsion liquid membrane (ELM) technique in a batch process for spentwash treatment. Water-oil-water type of emulsion was used to separate and concentrate the solutes resulting in $86 \%$ and $97 \%$ decrease in COD and BOD, respectively. Electrodialysis has been explored for desalting spentwash using cation and anion exchange membranes resulting in 50-60\% reduction in potassium content [46]. During treatment of winery and distillery wastewater by natural evaporation in ponds, formation of malodorous compounds induces harmful olfactory effects. The organic compounds are oxidised to $\mathrm{CO}_{2}$ and the nitrate is reduced to $\mathrm{N}_{2}$ (odourless compounds), without VFA formation. The preven- 
tive treatment of odours by nitrate addition was tested on an industrial scale in winery and distillery ponds [47]. Molasses spentwash containing $4 \%$ solids can be concentrated to a maximum of $40 \%$ solids in a quintuple-effect evaporation system with thermal vapor recompression [48, 49]. Combustion is also an effective method of on-site vinasse disposal as it is accompanied by production of potassium-rich ash [50] that can be used for land application.

Although many techniques have been explored for the treatment of melanoidins but they all are cost effective and produce large amount of sludge. So, to overcome these problem biological methods plays a crucial role in treatment of the melanoidins.

\section{Biological methods for the treatment of distillery effluent}

Microorganisms (bacteria/fungi/actinomycetes) due to their inherent capacity to metabolize a variety of substrate have been utilized since long back for biodegradation of complex, toxic and recalcitrant compounds, which cause severe damage to environment. Thus, these organisms have been exploited for biodegradation and decolorization of melanoidin pigment present in industrial wastes especially from distillery and fermentation industry. Biological treatment of molasses wastewater undergoes two subdivisions which include anaerobic treatment and aerobic treatment.

Anaerobic treatment is an accepted practice, and various high rate reactor designs have been tried at pilot and full scale operation. Aerobic treatment of anaerobically treated effluent using different microbial populations has also been explored. Majority of biological treatment technologies remove color by either concentrating the color into sludge or by partial or complete breakdown of the color molecules. These methods are discussed in detail in the following section.

\subsection{Anaerobic treatment /reactors}

In the anaerobic treatment of wastewater, the energy is extracted from the waste components without the introduction of air or oxygen. The anaerobic treatment of wastewater has now emerged as an energy saving wastewater treatment technology. It involves biological processes that takeplacein theabsence of oxygen and in which organicmaterials are degraded to produce biogas [51]. Molasses wastewater treatment using anaerobic process is a very promising reemerging technology, which presents interesting advantages as compared to classical aerobic treatment. It produces very little sludge, requires less energy and can be successfully operated at high organic loading rates; also, the biogas thus generated can be utilized for steam generation in the boilers thereby meeting the energy demands of the unit [52].

In India, the traditional method for this type of wastewater treatment involved sequestration in anaerobic lagoons during the dry season, followed by release in to the river. Anaerobic lagoons afford the simplest form of treatment to distillery effluent. Drawbacks of such form of treatment are the requirement of large land area, odour nuisance, and chances of ground water pollution. Since the development of the UASB process in the 1970s, this process has been 
widely applied for the treatment of industrial effluents. Effluents from alcohol producing industries are mostly highly polluted and therefore in principle very suitable for anaerobic treatment. Distilleries use different kinds of raw materials such as sugar cane juice, sugar cane molasses, sugar beet molasses, wine or corn for the production of alcohol [40]. The use of different materials and the different processes applied, resulted the production of wide variety of effluent. The process conditions under which good results of the anaerobic process are obtained depend heavily on the type of distillery effluent being treated. The choice of the right set of process parameters for every type of distillery effluent has shown to be of crucial importance for the anaerobic process. Bhoi et al. [53] worked on treatability studies of black liquor by upflow anaerobic sludge blanket reactor. This was deals with the feasibility studies of anaerobically treated black liquor along with the readily degradable synthetic wastewater (SWW) in a bench-scale upflow anaerobic sludge blanket reactor (UASBR). Treatment has been carried out in four phases of operation. In the first phase, 100\% of SWW prepared from molasses was used. In the other phases of operation, $10 \%, 20 \%$, and $30 \%$ of the SWW chemical oxygen demand (COD) was replaced by Black liquor COD successively. In each of the operation phases, the composition of the feed was not changed until COD reduction and gas production were stabilized. The entire operation took 509 days. The results indicate that the COD removal efficiency exhibited a decreasing trend with increase in the percentage of black liquor and apparently, UASB cannot be used as a treatment option for SWW containing more than $20 \%$ black liquor. Farhadian et al. [54] studied the treatment of strong beet sugar wastewater by an upflow anaerobic fixed bed (UAFB) at pilot plant scale. Reactors filled with standard industrial packing and inoculated with anaerobic culture (chicken manure, cow manure, anaerobic sludge digested from domestic wastewater) at $32-34{ }^{\circ} \mathrm{C}$ with $20 \mathrm{hrs}$ hydraulic retention time (HRT) and influent COD ranging between 2000-8000 $\mathrm{mgL}^{-1}$ showed the efficiency of organic content reduction in the reactor ranged from $75 \%$ to $93 \%$. The reactor filled with standard pall rings made of polypropylene with an effective surface area of 206 $\mathrm{m}^{2} \mathrm{~m}^{-3}$ performed best in comparison to the reactor filled with cut polyethylene pipe 134 $\mathrm{m}^{2} \mathrm{~m}^{-3}$ and reactor filled with PVC packing $\left(50 \mathrm{~m}^{2} \mathrm{~m}^{-3}\right)$. There was $2-7 \%$ decrease in efficiency with PE while it was $10-16 \%$ in case of PVC when compared to standard pall rings. Distillery waste tertiary treatment in a laboratory stabilization pond was evaluated. Effluents from a combined laboratory-scale anaerobic filter-aerobic trickling filter process were used as the influent. The effect of the hydraulic retention time (HRT) in the range of 5 - 30 days was evaluated at influent total chemical oxygen demand (TCOD) in the range of $271-5286 \mathrm{mgL}^{-1}$ $\left(\mathrm{BOD}_{5}\right.$ in the range of $\left.66-1212 \mathrm{mgL}^{-1}\right)$. TCOD and $\mathrm{BOD}_{5}$ removals of up to $54 \%$ and $74 \%$, respectively, were obtained for the most concentrated influent used at 30 days of HRT. The effect of the HRT on TCOD and $\mathrm{BOD}_{5}$ removal efficiencies followed an exponential relationship. An empirical equation adequately described the effect of the organic surface-loading rate on the process efficiency.

The pond acted as an intermediate flow pattern between completely mixed flow and plugflow. It was found that a second-order model fit in well with the experimental results of organic matter removal rate and effluent substrate concentration. The second-order kinetic constant was found to be $\mathrm{KS}=0.23 \mathrm{mg} \mathrm{BOD}_{5} / \mathrm{mg}$ TSS day. The proposed model accurately predicted the behaviour of the pond showing deviations between the experimental and theoretical values 
of effluent substrate concentrations equal to or lower than 11\% [55]. Sharma et al. [56] worked on the effect of nutrients supplementation on anaerobic sludge development and activity for treating distillery effluent. Startup of laboratory anaerobic reactors and treatment efficiency were investigated by supplementing the distillery effluent feed with macronutrients $(\mathrm{Ca}, \mathrm{P})$ and micronutrients (Ni, Fe and $\mathrm{Co}$ ) under mesophilic conditions. Calcium and Phosphate were detrimental to the treatment efficiency and sludge granulation. Traces of salt of Iron, nickel and cobalt individually and in combinations improved the COD removal efficiency and sludge granulation process.

Driessen et al. [57] studied on the anaerobic treatment of distillery effluent with the UASB process Special attention was given to the treatment of effluents from sugar cane based distilleries with very high COD concentration of 60000 to $160000 \mathrm{mg}$ COD. Despite expected toxicity problems. On the other hand, two identical UASB reactors operated in parallel as duplicates for 327 days for the treatment of malt whisky pot ale and achieved COD reductions of up to $90 \%$ for influent concentrations of $3526-52126 \mathrm{mgL}^{-1}$. When the OLRs of $15 \mathrm{~kg} \mathrm{~m}^{-3}$ day and above were used, the COD removal efficiency dropped to less than $20 \%$. A mesophilic two stage system consisting of an anaerobic filter (AF) and an UASB reactor was found suitable for anaerobic digestion of distillery waste, enabling better conditions for the methanogenic phase [58]. Immobilization of bacteria in biofilm and on bioflocs is a crucial step in anaerobic degradation because of advantages such as higher activities, higher COD removal percent at short hydraulic retention times and better tolerance to disturbances such as toxic and organic shock loadings. At the same time there were certain disadvantages as well because in addition to some readily biodegradable matter, vinasses contain compounds like phenols, which were toxic to bacteria and inhibit the digestion. Also, due to seasonal nature of many of these industries and the absence of microorganisms in vinasses capable of carrying out anaerobic digestion, long incubation periods are required for the start-up stage. Besides, other operational problems in anaerobic digestion such as low growth rate of anaerobic bacteria and the loss of biomass in systems with high hydraulic rates frequently does not achieve a satisfactory purification of vinasses [59]. The formation of $\mathrm{H}_{2} \mathrm{~S}$ in anaerobic reactors is the result of the reduction of oxidized sulphur compounds. Methanogenic bacteria can tolerate sulphide concentration up to $1000 \mathrm{mgL}^{-1}$ total sulphide. A complete loss of methane production occurred at $200 \mathrm{mgL}^{-1}$ of un-ionized $\mathrm{H}_{2} \mathrm{~S}$ during digestion of flocculent sludge. Anaerobic contact process incorporating an ultra filtration (UF) unit was used to treat distillery wastewater characterized by high and low carbon to nitrogen concentrations. This treatment system showed methane yield of up to $0.6 \mathrm{~m}^{3} \mathrm{~kg}^{-1} \mathrm{VS}$ and removed up to $80 \%$ of the volatile acids [60]. Two-phase anaerobic digestion of alcohol stillage proved to be superior to the single-phase process in terms of substrate loading rate and methane yield, without affecting the treatment performance [61]. While maintaining BOD and COD reduction of $85 \%$ and $65 \%$ respectively, the twophase achieved methane yield three times that of single-phase system.

Harada et al. [62] reported 39-67\% COD removal, with a corresponding BOD removal of over $80 \%$. The results suggested that the wastewater contained high concentration of refractile compounds; this, in turn, affected the microbial population in the sludge granules. Generally, the predominant genera of methanogens in granular sludge are Methanobacterium, Methano- 
brevibacter, Methanothrix and Methanosarcina [63]; however, the predominance of Methanothrix in granular sludge is most essential for the establishment of a high performance UASB process. In this study, abundance of Methanosarcina sp. was observed whereas Methanothrix sp. was present to a lesser extent thereby indicating that the latter was more sensitive to refractile compounds. Influence of reactor configuration on fermentative hydrogen $\left(\mathrm{H}_{2}\right)$ production and substrate degradation was evaluated employing anaerobic mixed consortia. Reactors were operated at acidophilic ( $\mathrm{pH}$ 6.0) condition employing designed synthetic wastewater as substrate at an organic loading rate of $3.4 \mathrm{Kg} \mathrm{COD} / \mathrm{m}^{3} /$ day with a retention time of $24 \mathrm{hrs}$ at $28 \pm 2{ }^{\circ} \mathrm{C}$. Experimental data enumerated the influence of reactor configuration on both $\mathrm{H}_{2}$ production and wastewater treatment. Biofilm reactor $\left(28.98 \mathrm{mmol} \mathrm{H}_{2} /\right.$ day; $1.25 \mathrm{Kg}$ $\mathrm{COD} / \mathrm{m}^{3} /$ day) showed relatively efficient performance over the corresponding suspended growth configuration (20.93 $\mathrm{mmol} \mathrm{H}_{2} /$ day; $1.08 \mathrm{Kg} \mathrm{COD} / \mathrm{m}^{3} /$ day). Specific $\mathrm{H}_{2}$ yields of 6.96 mmol H $\mathrm{H}_{2} / \mathrm{g}$-COD $\mathrm{L}_{\mathrm{L}}$-day $\left(19.32 \mathrm{mmol} \mathrm{H}_{2} / \mathrm{g}-\mathrm{COD}_{\mathrm{R}} /\right.$ day) and $5.03 \mathrm{mmol} \mathrm{H}_{2} / \mathrm{g}-\mathrm{COD}_{\mathrm{L}} /$ day $(16.10$ mmol $\mathrm{H}_{2} / \mathrm{g}-\mathrm{COD}_{\mathrm{R}} /$ day) were observed during stabilized phase of operation of biofilm and suspended growth reactors respectively. Higher concentration of VFA generation was observed in the biofilm reactor. Both the configurations recorded higher acetate concentration over other soluble metabolites indicating the dominance of acid-forming metabolic pathway during the $\mathrm{H}_{2}$ production process [64]. A lab-scale anaerobic hybrid (combining sludge blanket and filter) reactor was operated in a Continuous mode to study anaerobic biodegradation of distillery effluent. The study demonstrated that at optimum hydraulic retention time (HRT), 5 days and organic loading rate (OLR), $8.7 \mathrm{~kg}$ COD $/ \mathrm{m}^{3} \mathrm{~d}$, the COD removal efficiency of the reactor was $79 \%$. The anaerobic reduction of sulfate increases sulfide concentration, which inhibited the metabolism of methanogens and reduced the performance of the reactors. The kinetics of biomass growth i.e. yield coefficient $(Y, 0.0532)$ and decay coefficient $(\mathrm{Kd}, 0.0041$ $\mathrm{d}^{-1}$ ) was obtained using Lawrence and McCarty model. However, this model failed in determining the kinetics of substrate utilization. Bhatia et al. [65] model having inbuilt provision of process inhibition described the kinetics of substrate utilization, i.e. maximum rate of substrate utilization and inhibition coefficient values. Modeling of the reactor demonstrated that Parkin et al. [66], and Bhatia et al. [65] models, both, could be used to predict the effluent substrate concentration. However, Parkin et al. [66] model predicts effluent COD more precisely (within $\pm 2 \%$ ) than Bhatia et al. [65] model (within $\pm 5-20 \%$ ) of the experimental value. Karhadkar et al. [67] model predicted biogas yield within $\pm 5 \%$ of the experimental value. Besides these anaerobic treatments another treatment i.e. aerobic treatment is required for the safe disposal of effluent in the environment.

\subsection{Aerobic treatment}

Anaerobically treated distillery wastewater still contains high concentrations of organic pollutants and then cannot be discharged directly. The partially treated effluent has high BOD, COD and suspended solids. It can reduce the availability of essential mineral nutrients by trapping them into immobilized organic forms, and may produce phytotoxic substances during decomposition. Stringent regulations on discharge of colored effluent impede direct discharge of anaerobically treated effluent [52]. Therefore, aerobic treatment of sugarcane molasses wastewater has been mainly attempted for the decolorization of the major colorant, 
melanoidins, and for reduction of the COD and BOD. A large number of microorganisms such as bacteria (pure and mixed culture), cyanobacteria, yeast and fungi have been isolated in recent years and are capable of degrading melanoidins and thus decolorising the molasses wastewater. The aerobic methods have been described below.

\subsubsection{Bacterial treatment}

Numerous bacteria capable of melanoidins decolorization have been reported. Spent wash is pollution intensive wastewater generated by distilleries. Its dark brown color is due to recalcitrant melanoidin pigments. Bacterial cultures were screened for their ability to degrade these pigments.

Recently Lactic acid bacteria (Lactobacillus coryniformis, Lactobacillus sakei, Lactobacillus plantarum, Weisella soli, Pediococcus parvulus, Pediococcus pentosaceus) were used to decolorise the melanoidins. The isolate Lactobacillus plantarum exhibit $44 \%$ decourisation of melanoidins [68]. An effort has also been made by the Kryzwonos [69] using the consortia of genus Bacilli to decolorize the melanoidins. Two mixed bacterial cultures of the genus Bacillus (C1 and C2) were tested for color removal ability. Similarly Yadav and Chandra [70] developed the consortia Proteus mirabilis (IITRM5; FJ581028), Bacillus sp. (IITRM7; FJ581030), Raoultella planticola (IITRM15; GU329705) and Enterobacter sakazakii (IITRM16, FJ581031) in the ratio of 4:3:2:1. This consortia was responsible for the $75 \%$ decolorization of melanoidins within 10 days (Figure 3).

The isolate Alcaligenes faecalis strain $\mathrm{SAG}_{5}$ showed $72.6 \%$ decolorization of melanoidins at optimum $\mathrm{pH}(7.5)$ and temperature $\left(37^{\circ} \mathrm{C}\right)$ on $5^{\text {th }}$ day of cultivation. The toxicity evaluation with mung bean (Vigna radiata) revealed that the raw distillery effluent was environmentally highly toxic as compared to biologically treated distillery effluent, which indicated that the effluent after bacterial treatment is environmentally safe [71]. The degradation of synthetic and natural melanoidins was studied by using the axenic and mixed bacterial consortium (Bacillus licheniformis (RNBS1), Bacillus sp. (RNBS3) and Alcaligenes sp. (RNBS4). Results have revealed that the mixed consortium was more effective compared to axenic culture decolorising $73.7 \%$ and $69.8 \% \%$ synthetic and natural melanoidins whereas axenic cultures RNBS1, RNBS3 and RNBS4 decolorized $65.88 \%, 62.5 \%$ and $66.1 \%$ synthetic and $52.6 \%, 48.9 \%$ and $59.6 \%$ natural melanoidins, respectively. The HPLC analysis of degraded samples has shown reduction in peak areas compared to controls, suggesting that decrease in color intensity might be largely attributed to the degradation of melanoidins by isolated bacteria [72]. Tondee and Sirianuntapiboon [73] isolated Lactobacillus plantarum No. PV71-1861 from pickle samples in Thailand. The strain showed the highest melanoidin pigment (MP) decolorization yield of $68.12 \%$ with MP solution containing glucose $2 \%$, yeast extract $0.4 \%, \mathrm{KH}_{2} \mathrm{PO}_{4} 0.1 \%, \mathrm{MgSO}_{4} 7 \mathrm{H}_{2} \mathrm{O} 0.05 \%$ and initial $\mathrm{pH} 6$ under static condition at $30^{\circ} \mathrm{C}$ within 7 days. But, it showed low growth and MP decolorization yields under aerobic conditions. Gel filtration chromatograms of the MP solutions showed that the small molecular weight fraction of MP solution was decolorized by the strain when the large molecular weight fraction still remained in the effluent. For application, the strain could apply to treat anaerobic treated-molasses wastewater (T-MWW) with high removal efficiency. The highest MP removal efficiencies and growth yield of $76.6 \%$ and 


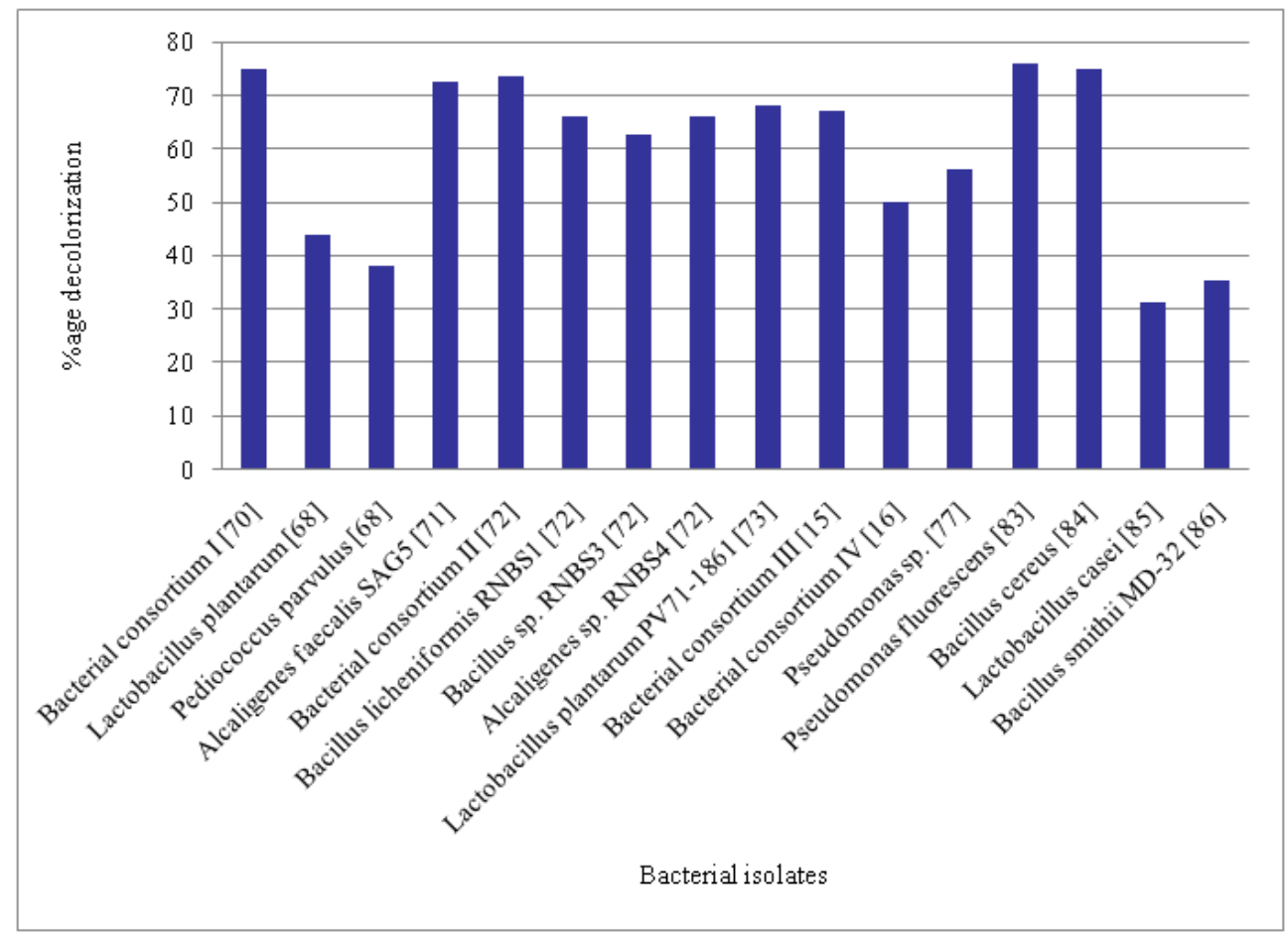

Figure 3. Melanoidin decolorization activity by different bacterial cultures. Bacterial consortium I: Proteus mirabilis (IITRM5; FJ581028), Bacillus sp. (IITRM7; FJ581030), Raoultella planticola (IITRM15; GU329705) and Enterobacter sakazakii (IITRM16, FJ581031) in the ratio of 4:3:2:1[70]; Bacterial consortium II: Bacillus licheniformis (RNBS1), Bacillus sp. (RNBS3) and Alcaligenes sp. (RNBS4) [72]; Bacterial consortium III: Pseudomonas aeruginosa PAO1, Stenotrophomonas maltophila and Proteus mirabilis [15]; Bacterial consortium IV: Bacillus thuringiensis (MTCC 4714), Bacillus brevis (MTCC 4716) and Bacillus sp. (MTCC 6506) [16].

$2.6 \mathrm{mg} / \mathrm{ml}$, respectively, were observed with the T-MWW within 7 days of culture, and the effluent $\mathrm{pH}$ of the system was decreased to lower than 4.0 after 2-3 days operation.

The identification of culturable bacteria by $16 \mathrm{~S}$ rDNA based approach showed that the consortium composed of Klebsiella oxytoca, Serratia mercescens, Citrobacter sp. and unknown bacterium decolorise the synthetic melanoidins. In the context of academic study, prevention on the difficulties of providing effluent as well as its variations in compositions, several synthetic media prepared with respect to color and COD contents based on analysis of molasses wastewater, i.e., Viandox sauce $(13.5 \%, \mathrm{v} / \mathrm{v})$, caramel $(30 \%, \mathrm{w} / \mathrm{v})$, beet molasses wastewater $(41.5 \%, \mathrm{v} / \mathrm{v})$ and sugarcane molasses wastewater $(20 \%, \mathrm{v} / \mathrm{v})$ were used for decolorization using consortium with color removal 9.5\%, 1.13\%, 8.02\% and 17.5\%, respectively, within 2 days. However, Viandox sauce was retained for further study. The effect of initial $\mathrm{pH}$ and Viandox concentration on decolorization and growth of bacterial consortium were further determined. The highest decolorization of $18.3 \%$ was achieved at $\mathrm{pH} 4$ after 2 day of incubation [74]. Mohana et al. [15] isolated the microorganisms that were capable of decolorizing anaerobically treated distillery 
spent wash. A bacterial consortium DMC comprising of three bacterial cultures was selected on the basis of rapid effluent decolorization and degradation, which exhibited $67 \pm 2 \%$ decolorization within $24 \mathrm{hrs}$ and $51 \pm 2 \%$ chemical oxygen demand reduction within $72 \mathrm{hrs}$ when incubated at $37{ }^{\circ} \mathrm{C}$ under static condition in effluent supplemented with glucose $0.5 \%, \mathrm{KH}_{2} \mathrm{PO}_{4} 0.1 \%$, $\mathrm{KCl} 0.05 \%$ and $\mathrm{MgSO}_{4} .7 \mathrm{H}_{2} \mathrm{O} 0.05 \%$. Addition of organic or inorganic nitrogen sources did not support decolorization. The cultures were identified as Pseudomonas aeruginosa PAO1, Stenotrophomonas maltophila and Proteus mirabilis by the $16 \mathrm{~S}$ rDNA analysis. Kumar and Chandra [16] studied on the decolorization of synthetic melanoidins (i.e., GGA, GAA, SGA and SAA) by three Bacillus isolates Bacillus thuringiensis (MTCC 4714), Bacillus brevis (MTCC 4716) and Bacillus sp. (MTCC 6506). Significant reduction in the values of physicochemical parameters was noticed along with the decolorization of all four melanoidins (10\%, v/v). B. thuringiensis (MTCC 4714) caused maximum decolorization followed by B.brevis (MTCC4716) and Bacillus sp.(MTCC6506). A mixed culture comprised of these three strains was capable of decolorizing all four melanoidins. The medium that contained glucose as sole carbon source showed $15 \%$ more decolorization than that containing both carbon and nitrogen sources. Melanoidin SGA was maximally decolorized (50\%) while melanoidins GAA was decolorized least in the presence of glucose as a sole energy source. Acetogenic bacteria are capable of oxidative decomposition of melanoidins. Adikane et al. [75] worked decolorization of molasses spent wash (MSW) in absence of any additional carbon or nitrogen source using soil as inoculum. A decolorization of $69 \%$ was obtained using $10 \%(\mathrm{w} / \mathrm{v})$ soil and $12.5 \%(\mathrm{v} / \mathrm{v})$ MSW after 7 days incubation. Optimized parameters including days 6 days, $\mathrm{pH}$ 6, MSW 12.5\% and soil concentration 40\%, were obtained for maximum decolorization. A decolorization of $81 \%$ was achieved using $10 \%$ soil and $12.5 \%$ MSW after 18 days incubation in absence of any media supplement. Nearly $12 \%$ reduction in decolorization activity of the soil sample was observed over a period of 12 months when stored at $6{ }^{\circ} \mathrm{C}$. It could be concluded that the decolorization of MSW might be achieved using soil as inoculum without addition of chemical amendments. On the other hand, Bacillus megaterium SW3 and Bacillus subtilis SW8 were used for decolorization and bioremediation of DMSW. Both bacterial isolates were grown well in $7.5 \%(\mathrm{v} / \mathrm{v})$ diluted digested spent wash supplemented with glucoseand urea as a readily availablecarbon and nitrogen source. Optimum condition for growth and DMSW decolorization were at $\mathrm{pH} 7.2$, temperature $37^{\circ} \mathrm{C}$, glucose $5 \%$ $(\mathrm{w} / \mathrm{v})$, and urea $2 \%(\mathrm{w} / \mathrm{v})$ in a minimal salt medium. The maximum decolorization $(51 \%, 52.5 \%$ and $57 \%$ ) and COD reduction (53\%, 54.5\% and 59\%) was found after 5 days of incubation under the optimized condition were achieved for cultures SW3, SW8 and consortia (SW3 + SW8) respectively [76].

Chavan et al. [77] isolated a Pseudomonas sp. and studied for degradation of recalcitrant melanoidin pigment. The optimum conditions for decolorization were $\mathrm{pH} 6.8-7.2$, temperature $30-35{ }^{\circ} \mathrm{C}$ and glucose $0.4 \%(\mathrm{w} / \mathrm{v})$. The maximum decolorization up to $56 \%$ and $63 \%$ reduction in COD of the spent wash could be achieved after 72 hrs by the microbial treatment. Spectrophotometric and HPLC analysis of treated effluent confirmed biodegradation of melanoidin pigments by the isolate. This approach could be used to develop a cost-effective, eco-friendly biotechnology package for the bioremediation of spent wash before its disposal. 
Ghosh et al. [78] worked on enrichment and identification of bacteria capable of reducing COD of anaerobically treated molasses spent wash. The isolates were grouped into six haplotypes by amplified ribosomal DNA restriction analysis (ARDRA) and BOX-PCR. They showed maximum similarity to six genera viz. Pseudomonas, Enterobacter, Stenotrophomona, Aeromonas, Acinetobacter and Klebsiella. The extent of COD (44\%) reduced collectively by the six strains was equal to that reduced individually by Aeromonas, Acinetobacter, Pseudomonas and Enterobacter. With spent wash as sole carbon source, the COD reducing strains grew faster at $37^{\circ} \mathrm{C}$ than $30^{\circ} \mathrm{C}$. Sirianuntapiboon et al. [79] isolated 170 strains of acetogenic bacteria, a strain No.BP103 showed the highest decolorization yield when cultivated at $30{ }^{\circ} \mathrm{C}$ for 5 days in molasses pigments medium containing glucose $3.0 \%$, yeast extract $0.5 \%, \mathrm{KH}_{2} \mathrm{PO}_{4} 0.1 \%$ and $\mathrm{MgSO}_{4} .7 \mathrm{H}_{2} \mathrm{O}$ $0.05 \%$ and the $\mathrm{pH}$ adjusted to 6.0 . In addition this strain could decolorise $32.3 \%$ and $73.5 \%$ of molasses pigments in stillage and anaerobically treated molasses wastewater, both supplementing glucose $3.0 \%$ yeast extract $0.5 \%, \mathrm{KH}_{2} \mathrm{PO}_{4} 0.1 \%$ and $\mathrm{MgSO} 4.7 \mathrm{H}_{2} \mathrm{O} 0.05 \%$. However without nutrients supplement, the decolorization yields were $9.75 \%$ and $44.3 \%$ respectively. In a replacement culture system involving six time replacement (30days), the strain No. BP103 Showed a constant decolorization yield of $72.0 \%$ to $84.0 \%$ and caused decreases of biological oxidation demand and chemical oxygen demand values of approximately $58.5 \%$ to $82.2 \%$ and $35.5 \%$ to $71.2 \%$, respectively. Under a periodical feeding system, the decolorization yield was 30.0 to $45.0 \%$. Cibis et al. [80] achieved biodegradation of potato slops (distillation residue) by a mixed population of bacteria under thermophilic conditions up to $60^{\circ} \mathrm{C}$. A COD removal of $77 \%$ was achieved under non-optimal conditions.

Savant et al. [81] isolated a novel acid-tolerant, hydrogenotrophic methanogenic isolate ATM ${ }^{\mathrm{T}}$, using enrichment culture technique at $\mathrm{pH} 5$ using slurry from an acidogenic digester running on alcohol distillery waste. The original $\mathrm{pH}$ of the slurry was 5.7 and the volatile fatty acid concentration was $9000 \mathrm{ppm}$. Cells of isolate $\mathrm{ATM}^{\mathrm{T}}$ were Gram-positive, non-motile and 0.3-0.5 $\mu \mathrm{m}$ in size. They did not form spores. The isolate could grow in the $\mathrm{pH}$ range 5.0-7.5, with maximum growth at $\mathrm{pH}$ 6.0. The optimum temperature for growth was $35^{\circ} \mathrm{C}$. Morphological and biochemical characteristics of the isolate, together with the $16 \mathrm{~S}$ rDNA sequence analysis, clearly revealed that the isolate could be accommodated within any of the existing species of the genus Methanobrevibacter. Therefore, it is proposed that a novel species of the genus Methanobrevibacter should be created for this isolate, Methanobrevibacter acididurans sp. nov., and the type strain is strain $\mathrm{ATM}^{\mathrm{T}}$. Ghosh et al. [82] studied on the application of two bacterial strains, Pseudomonas putida U and Aeromonas strain Ema, in a two-stage column bioreactor to reduce $C O D$ and the color of anaerobic treated spent wash under aerobic conditions. $P$. putida reduced the COD and color by $44.4 \%$ and $60 \%$.

Dahiya et al. [83] worked on decolorization of molasses wastewater by cells of Pseudomonas fluorescens. Decolorization was $76 \%$ under nonsterile conditions in four days at $30{ }^{\circ} \mathrm{C}$. Immobilised cells could be reused for decolorization activity. However, in subsequent cycles, this was found to decrease from $76 \%$ to $50 \%$ and from $50 \%$ to $24 \%$. Decolorization activity was regenerated from $30 \%$ to $45 \%$ by recultivating the immobilised cells in a fresh growth medium. Cellulose carrier coated with collagen was found to be most effective carrier, which produced the highest decolorization activity of $94 \%$ in a day process. This carrier could be reused with 
$50 \%$ of the decolorization activity retained until the seventh day. Jain et al. [84] studied on degradation of anaerobically digested distillery wastewater by three bacterial strains, viz. Xanthomonas fragariae, Bacillus megaterium and Bacillus cereus in free and immobilized form, isolated from the activated sludge of a distillery wastewater treatment plant. The removal of COD and color with all the three strains increased with time up to 48 hrs and only marginal increase in COD and color removal efficiency was observed beyond this period up to $72 \mathrm{hrs}$. After this period, removal efficiency remained fairly constant up to $120 \mathrm{hrs}$. The maximum COD and color removal efficiency varied from 66 to $81 \%$ and 65 to $75 \%$ respectively for both free and immobilized cells of all the three strains. The strain Bacillus cereus showed the maximum efficiency of COD (81 \%) and color (75\%) removal out of the three strains.

Masaharu et al. [85] studied on the screening of acid-forming facultative anaerobes for their decolorizing ability with the distilled wastewater (DWDA) produced during the alcoholic fermentation of cane molasses was carried out. On the primary screening, 113 strains, which were isolated from enrichment cultures of various plant and animal samples or soil samples showed decolorizing activity on modified GYP medium containing 10\% (v/v) distilled wastewater. Strain SM-3 was selected as the best strain. This strain decolorized $31.4 \%$ of molasses pigment at a concentration of $10 \%(\mathrm{v} / \mathrm{v})$ distilled wastewater supplemented with $1 \%$ glucose within 5 days at $30^{\circ} \mathrm{C}$ under semi-anaerobic conditions. The main DWDA was found in the cell-free extract and cell membrane fractions. The strain was identified as Lactobacillus casei. Kambe et al. [86] screened out various microorganisms for their ability to decolorise molasses wastewater under thermophilic and anaerobic conditions. Strain MD-32, which was newly isolated from a soil sample, was selected as the best strain. From taxonomical studies, the strain was concluded to belong to the genus Bacillus, most closely resembling B. smithii. The strain decolorized $35.5 \%$ of molasses pigment within 20 days at $55{ }^{\circ} \mathrm{C}$ under anaerobic conditions but no decolorization activity was observed when it was cultivated aerobically.

At all the concentration tested molasses pigment was effectively decolorized by MD-32, with decolorization yields of around 15\% within 2 days. The molecular weight distribution as determined by gel filtration chromatography revealed that the decolorization of molasses pigment by the isolated strain is accompanied by a decrease in not only small molecules but also large ones. Sirianuntapiboon [87] isolated acid forming bacteria from vegetables, fruits and fermented food samples. They were primary screened to select the strains which had decolorization activity. The results showed that 50 isolates had decolorization activity on solid medium (clear zone). Among these, the strains No. BP103 and No. 13A gave the highest decolorization activity in the liquid medium which contained molasses pigments. Fructose was the most suitable carbon source for both strains for decolorizing molasses pigments. The optimal concentration of fructose in the media for highest decolorizing activity was $2.0 \%$. For the effects of nitrogen source on decolorization activity, the organic nitrogen compounds were the best nitrogen sources for both strains. The decolorization activity of the strain No. 13A and No. BP103 were $80.5 \%$ and $82.0 \%$, respectively when the nitrogen source was yeast extract. At the optimal conditions, the decolorizing activity of the strains No. 13A and BP103 were $90.5 \%$ and $96.7 \%$, respectively. Strain No. 13A and No. BP103 were identified as Acetobacter acetii. Ohmomo et al. [88] performed screening of facultative anaerobes with melanoidin decolorizing 
activity (MDA). Strains were isolated from stored wastewater of an alcohol fermentation involving molasses. One of them, strain W-NS, showed high and stable MDA, and was identical with Lactobacillus hilgardii. The decolorization yield of this strain under the optimal conditions was improved to $40 \%$ by immobilization of cells within Ca- alginate gel.

\subsubsection{Fungal treatment}

Increasing attention has been directed towards utilizing microbial activity for decolorization of molasses wastewater. Several reports have indicated that some fungi in particular have such a potential [89]. One of the most studied fungus having ability to degrade and decolorise distillery effluent is Aspergillus such as Aspergillus fumigatus G-2-6, Aspergillus niger, Aspergillus niveus, Aspergillus fumigatus UB260 brought about an average of $69-75 \%$ decolorization along with $70-90 \%$ COD reduction [22, 90-92]. Previous studies showed that the white-rot fungus Phanerochaete chrysosporium could remove color and total phenols from the sugar refinery effluent [93]. Ohmomo et al. [94] reported the continuous decolorization of molasses wastewater in a bubbling column reactor with Coriolus versicolor immobilized within Ca-alginate gel. Later, Ohmomo et al. [95] used autoclaved mycelium of Aspergilus oryzae Y-2-32 that adsorbed lower weight fractions of melanoidins and degree of adsorption was influenced by the kind of sugars used for cultivation. The wine distilleries produce large volume of wastewater having phenolic compounds, which give a high inhibitory and antibacterial activity to this wastewater, thus slowing down the anaerobic digestion process. Partial elimination of these phenolics compounds was obtained by using Geotrichum candidum [96]. Rhizoctonia sp. D90 decolorized molasses melanoidins medium and a synthetic melanoidin medium by $87.5 \%$ and $84.5 \%$, respectively, under experimental conditions [97] (Figure 4). Murata et al. [98] isolated a fungus Streptomyces werraensis TT 14 from soil that decolorized the model melanoidin, the decolorization rate being $64 \%$ in the optimal medium of $\mathrm{pH}-5.5$ and $45 \%$ in a synthetic medium. There was virtually no difference in the UV-VIS absorption spectra of the microbially treated melanoidin and control. The peaks of the gel permeation chromatogram for the treated melanoidin and for the control showed the same retention times, but lower molecular weight compounds increased in the decolorized melanoidin. Kida et al. [99] Aspergillus awamori var. kawachi has been used for production of single cell protein from Japanese distillery wastewater after aerobic cultivation.

Fujita et al. [100] also considered the decolorization of melanoidin present in an effluent with Coriolus hirsutus. The aim of this study was to find a suitable industrial biological treatment process for efficient decolorization of sugar refinery effluent. White-rot fungi have been reported to be capable of decolorizing melanoidin containing wastewaters. Previous studies showed that the white-rot fungus Phanerochaete chrysosporium can remove color and total phenols from the sugar refinery effluent [93]. Several studies have been reported for decolorizing the distillery effluent using fungi. Fumi et al. [101] worked on the optimisation of long term activated sludge treatment of winery wastewater. The results obtained in work carried out in order to verify the overall efficiency of full-scale, long-term, activated-sludge treatment of winery wastewater. The analytical data showed the high removal of COD during the whole experimentation period and with various working parameters. Sludge production was lower than that produced by ordinary 


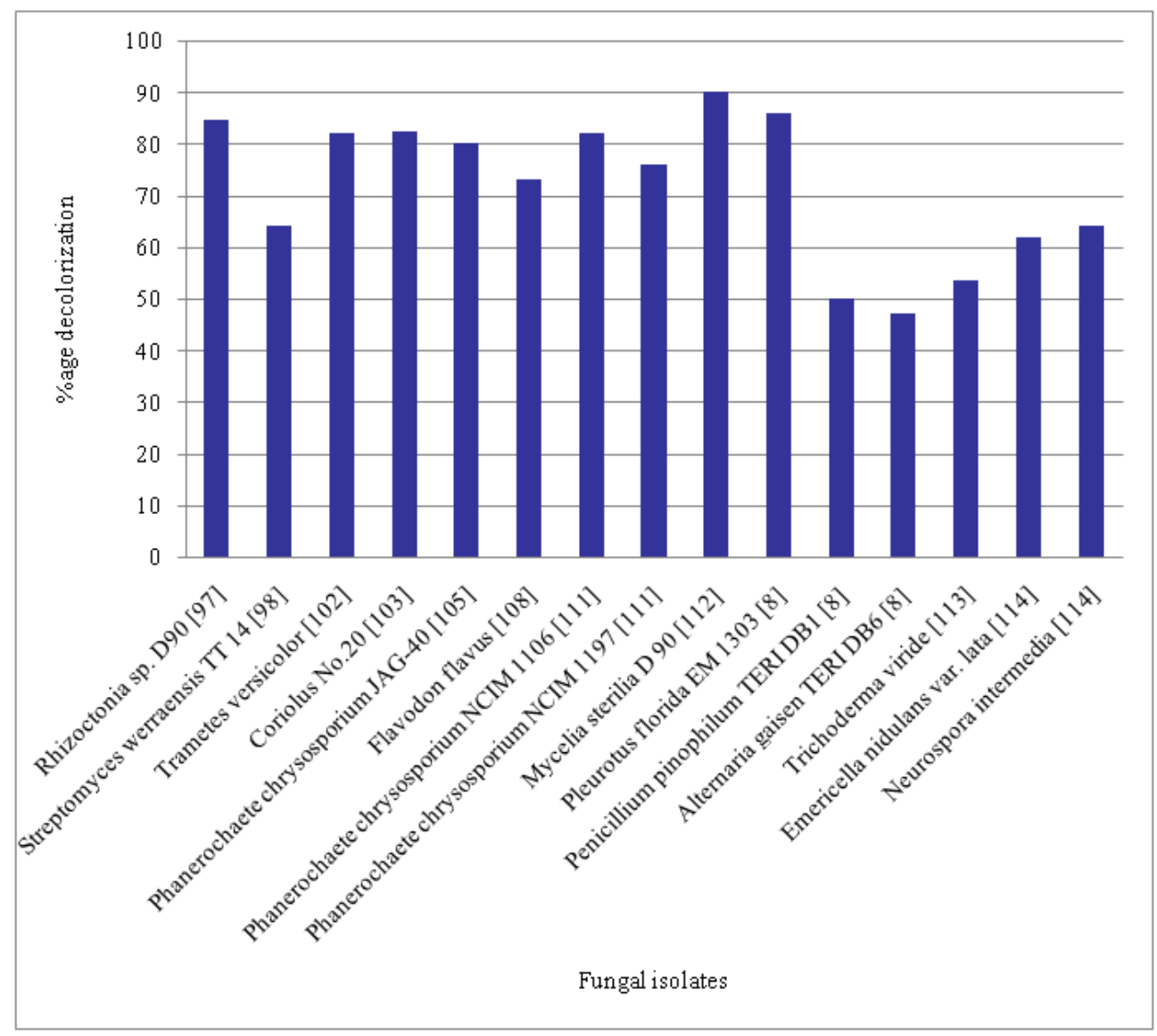

Figure 4. Melanoidin decolorization activity by different fungi.

activated-sludge plants. Miranda et al. [90] worked on color elimination from molasses wastewater by Aspergillus niger. Color elimination by Aspergillus niger from wastewater was studied. The influences of the nutrient concentrations, initial $\mathrm{pH}$ and carbon source on this color elimination were analyzed. During the batch process, through all experiments the maximal color elimination was attained after 3 or 4 days in the culture. Batch processes showed a maximal color elimination of $69 \%$ when $\mathrm{MgSO}_{4}, \mathrm{KH}_{2} \mathrm{PO}_{4}, \mathrm{NH}_{4} \mathrm{NO}_{3}$ and a carbon source were added to the wastewater. The continuous process, with the same nutrient concentrations, showed less color removal and the decolorization activity was maintained for only 4 days. Benito et al. [102] studied on decolorization of wastewater from an alcoholic fermentation process with Trametes versicolor. Tests varying the concentrations of carbon source, nutrients, initial $\mathrm{pH}$ and mycelia were carried out in order to analyze their influence on the percentage decolorization, COD removal and decrease of ammonium content of the wastewater. In this way, $82 \%$ color elimination, $77 \%$ COD removal and $36 \% \mathrm{~N}-\mathrm{NH}$ : decrease was attained. 
Another fungus, Coriolus No.20, belonging to the class basidiomycetes, can remove color substances from molasses wastewater (MWW). In the case of treatment of MWW solution, the decrease was $82.5 \%$ in darkness under optimal conditions. This decolorization was through the adsorption of melanoidin to the mycelium and the yield of adsorption was 9.67 and 12.2 $\mathrm{mg} \mathrm{g}^{-1}$ of mycelium as dry basic in the case of autoclaved mycelium and resting mycelium, respectively. The resting mycelium showed the highest adsorption yield (16.32 $\mathrm{mg} \mathrm{g}^{-1}$ of mycelium) when the melanoidins solution was supplemented with $20 \%$ glucose solution. In the fed-batch system, the strain showed a constant decolorization yield of $75 \%$ during four times replacements (32 days) in both untreated and treated MWW solutions. In the continuous feed system for decolorization of untreated MWW solution, 10\% of fresh untreated MWW solution was added every day after seven days of cultivation. The decolorization rate was constant (37.5\%) during 12 days of operation. In the continuous decolorization of concentrated untreated MWW solution, the strain showed a constant decolorization yield (about 70\%) during three times feeding of fresh concentrated untreated MWW solution. But I0 ml of $20 \%$ glucose solution had to be added after 13 days cultivation to keep the reducing sugar concentration in the culture broth at more than $1.0 \%$ [103].

Miyata et al. [26] worked on Manganese-Independent and Dependent decolorization of melanoidinusing fungi.Coriolushirsutus pelletsweregrowninamelanoidin-containing medium produced extracellular $\mathrm{H}_{2} \mathrm{O}_{2}$ up to $43 \mu \mathrm{m}$. However, nonenzymatic decolorization of melanoidin by $\mathrm{H}_{2} \mathrm{O}_{2}$, which has been previously reported, seemed very little in the fungal culture. The culture fluid contained two extracellular peroxidases, a manganese-independent peroxidase (MIP) and manganese peroxidase (MnP). Since both MIP and $\mathrm{MnP}$ showed melanoidindecolorizing activities in the presence of $\mathrm{H}_{2} \mathrm{O}_{2}$, it was resulted that melanoidin decolorization in the C. hirsutus culture involved the production of extracellular $\mathrm{H}_{2} \mathrm{O}_{2}$ and the peroxidases. Miyata et al. [104] studied on the combined use of activated sludge and the fungus Coriolus hirsutus. A white rot fungus, Coriolus hirsutus, exhibited a strong ability to decolorise melanoidin in cultures not supplemented with nitrogenous nutrients. Addition of peptone to the cultures lowered the ability of the fungus to decolorise melanoidin, but that of inorganic nitrogens, ammonium and nitrate did not bring about any marked reduction in the ability. It suggested an inhibitory effect of organic nitrogen on melanoidin decolorization. Therefore, for enhancing the decolorization of melanoidin in wastewaters by the fungus, activated sludge pretreatment of the wastewaters was expected to be effective, i.e. activated sludge is capable of converting available organic $\mathrm{N}$ into inorganic N. To confirm this, waste sludge heat treatment liquor (HTL), wastewater from a sewage treatment plant, was pretreated with activated sludge. In practice, pretreatment of HTL under appropriate conditions accelerated the fungal decolorization of HTL. In the pretreated HTL, the fungus was shown to produce a high level of manganese-independent peroxidase (MIP). Addition of Mn(I1) to the pretreated HTL caused a further increase in the decolorization efficiency of the fungus and a marked increase in the manganese peroxidase $(\mathrm{MnP})$ activity. Consequently, the increases in MIP and MnP activities were considered to play an important role in the enhanced ability of $C$. hirsutus to decolorise HTL.

Dahiya et al. [105] worked on decolorization of synthetic and spentwash melanoidins using the white-rot fungus Phanerochaete chrysosporium JAG-40. This fungus was isolated from the 
soil samples saturated with spilled molasses collected from a sugar mill. This isolate decolorized synthetic and natural melanoidins present in spentwash in liquid fermentation; up to $80 \%$ in 6 days at $30^{\circ} \mathrm{C}$ under aerobic conditions. A large inoculum size stimulated fungal biomass production, but this gave less decolorization of pigment; $5 \% \mathrm{w} / \mathrm{v}$ (dry weight) mycelial suspension was found optimum for maximum decolorization in melanoidin medium supplemented with glucose and peptone. Gel-filtration chromatography showed that larger molecular weight fractions of melanoidins were decolorized more rapidly than small molecular weight fractions. Malandra et al. [106] studied the microorganisms associated with a rotating biological contactor (RBC) treating winery wastewater. One of the yeast isolates was able to reduce the COD of synthetic wastewater by $95 \%$ and $46 \%$ within $24 \mathrm{hrs}$ under aerated and non aerated conditions, respectively. Kwak et al. [107] worked on effect of reaction $\mathrm{pH}$ on the photodegradation of model melanoidins. The wastewaters of molasses-based alcohol distilleries contain brown colored melanoidin pigments that are one of the major pollutants.

Ragukumar et al. [108] reported decolorization of such intensely brown colored molasses spent wash (MSW) by Flavodon flavus, a white-rot basidiomycete fungus isolated from a marine habitat. They attempted to improve the process of decolorization of MSW by this fungus by immobilization. Polyurethane foam-immobilized-fungus decolorized $10 \%$ diluted MSW by $60 \%$ and $73 \%$ by day 5 and 7 respectively. The immobilized fungus could be effectively used for a minimum of 3 cycles repeatedly to decolorise MSW. Besides decolorization, the fungus also removed the toxicity of MSW. Raghukumar and Rivonkar, [109] studied on the decolorization of molasses spent wash by the white rot fungus Flavodon flavus isolated from decomposting leaves of a sea grass, decolorized pigment in molasses spentwash (MSW) by $80 \%$ after 8 days of incubation, when used at concentrations of $10 \%$ and $50 \%$. Decolorizing activity was also present in the media prepared with half strength sea water. Decolorizing activity was also seen in low nitrogen medium, nutrient rich medium and in sugar cane bagasse medium. The percentage decolorization of MSW was highest when glucose or sucrose was used as a carbon source in the low nitrogen medium

On the other hand, Phanerochaete chrysosporium was used for the vinasse degradation under two different growth conditions. Vinasse was treated by P. chrysosporium in a liquid inoculum form, during 32 days at room temperature (approximately $25^{\circ} \mathrm{C}$ ) and at $39^{\circ} \mathrm{C}$. The chemical oxygen demand (COD), total phenol concentration and color removal were measured and there was a decrease in COD, phenolic concentration and color of $47.4 \%, 54.7 \%$ and $45.1 \%$ respectively, at room temperature and a decrease in $54.2 \%, 59.4 \%$ and $56.8 \%$ respectively at $39^{\circ} \mathrm{C}[110]$. Thakkar et al. [111] studied the biocatalytic decolorization of molasses by Phanerochaete chrysosporium. Bioremediation potential of Phanerochaete chrysosporium strains NCIM 1073, NCIM 1106 and NCIM1197 to decolorise molasses in solid and liquid molasses media was studied. Strains varied in the pattern of molasses decolorization on solid medium by giant colony method. Under submerged cultivation conditions, strain NCIM 1073 did not decolorise molasses while, strains NCIM 1106 and NCIM 1197 could decolorise molasses up to $82 \%$ and $76 \%$, respectively. Under stationary cultivation conditions, none of the strains could decolorise molasses.

Srianuntapiboon et al. [112] worked on three kinds of molasses wastewater collected from the stillage of an alcohol factory, and their chemical properties. Mycelia sterilia D 90 decolorized 
about $90 \%$ of the molasses pigment in 10 days and at the same time caused an about $80 \%$ decrease in the biological oxygen demand value when glucose $2.5 \%, \mathrm{NaNO}_{3} 0.2 \%, \mathrm{KH}_{2} \mathrm{PO}_{4}$ $0.1 \%$ and $\mathrm{MgSO}_{4} \cdot 7 \mathrm{H}_{2} \mathrm{O} 0.05 \%$ were added to the molasses wastewater from the stillage as nutrients. But without supplementation of the nutrients, the decolorization yield was only $17.5 \%$. Furthermore, this strain showed a decolorization yield of about $70 \%$ in 11 days and caused a decrease in the biological oxygen demand value of about $90 \%$ in 15 days under nonsterile conditions. In the fed-batch system, this strain showed a constant decolorization yield of about $80 \%$ and caused a decrease in the biological oxygen demand value of about $70 \%$.

Pant and Adholeya [8] isolated two fungal strains producing ligninolytic enzymes and having the potential to decolorise distillery effluent from the soil of a distillery effluent contaminated site. DNA was isolated from the pure cultures of these fungi and polymerase chain reaction (PCR) amplification of their internal transcribed spacer (ITS) region of nuclear ribosomal DNA was carried out. Further, the DNA was sequenced and the comparison of generated sequence with database led to their identification as Penicillium pinophilum TERI DB1 and Alternaria gaisen TERI DB6, respectively. These two isolates along with one isolate of Pleurotus florida EM 1303 were assessed for their ligninolytic enzyme activity in culture filtrate as well as after solid state fermentation on two substrates wheat straw and corncob powder. Ergosterol was measured to assess the growth of fungi on solid media. Both P. pinophilum TERI DB1 and A. gaisen TERI DB6 were found to produce laccase, manganese-dependent peroxidases $(\mathrm{MnP})$ and lignin peroxidases (LiP). The immobilized fungal biomass was used for decolorization of the post biomethanated wastewater from the distillery. Reduction in color up to the magnitude of $86 \%, 50 \%$ and $47 \%$ was observed with $P$. florida, P. pinophilum and A. gaisen respectively. In another study, the fungi Trichoderma viride showed the highest decolorization yield (53.5\%) when cultivated at $30{ }^{\circ} \mathrm{C}$ for 7 days in medium contained the molasses which was diluted to $40 \mathrm{gL}^{-1}$ in distilled water. The other Trichoderma species and Penicillium sp. also gave similar results of $40 \%-45 \%$. Decolorization yield was increased by adding peptone and yeast extract to the production medium except Penicillium sp. When the $\mathrm{pH}$ decreased below 5.0 after the incubation, the decolorization yield increased. Although reducing sugar in culture broth decreased with decreasing color intensity, there was no connection between protein utilization and decolorizing activity [113]. Two fungi (Emericella nidulans var. lata and Neurospora intermedia) have the capability to decolorise melanoidins. Maximum color was removed at $\mathrm{pH}$ 3, temperature $30{ }^{\circ} \mathrm{C}$, stirring $125 \mathrm{rpm}$, dextrose $(0.05 \%)$ and sodium nitrate $(0.025 \%)$ by both fungi. After optimization, there was two-fold increase in color removal from $38 \%$ to $62 \%$ (DF3) and $31 \%$ to $64 \%$ (DF4) indicating significance of Taguchi approach in decolorization of distillery mill effluent [114].

\subsubsection{Treatment by other microorganisms}

The treatment of anaerobically treated $10 \%$ distillery effluent using the microalga Chlorella vulgaris followed by Lemna minuscula resulted in 52\% reduction in color [115]. In another study, Kalavathi et al. [116] examined the degradation of $5 \%$ melanoidin by the marine cyanobacterium Oscillatoria boryana BDU 92181. The organism was found to release hydrogen peroxide, hydroxyl ions and molecular oxygen during photosynthesis resulting in $60 \%$ decolorization 
of distillery effluent. In addition, this study suggested that cyanobacteria could use melanoidin as a better nitrogen source than carbon. Further, cyanobacteria also excrete colloidal substances like lipopolysaccharides, proteins, polyhydroxybutyrate (PHB), polyhydroxy-alkanoates (PHA), etc. These compounds possess $\mathrm{COO}^{-}$and ester sulphate $\left(\mathrm{OSO}^{3-}\right)$ groups that can form complexes with cationic sites thereby resulting in flocculation of organic matter in the effluent. It was observed that the strain Oscillatoria resulted in almost complete color removal (96\%) whereas Lyngbya and Synechocystis were less effective resulting in 81 and 26\% color reduction, respectively [117]. The consortium of the three strains showed a maximum decolorization of $98 \%$. This was attributed to adsorption in the initial stages followed by degradation of organic compounds which dominated in the subsequent stages. Sirianuntapiboon et al. [31] worked on decolorization of molasses wastewater by Citeromyces sp. WR-43-6. 205 yeast strains isolated from Thai-fruit samples were screened, and isolated strain No. WR-43-6 showed the highest decolorization yield $(68.91 \%)$ when cultivated at $30^{\circ} \mathrm{C}$ for 8 days in a molasses pigments solution containing glucose $2.0 \%$, sodium nitrate $0.1 \%$ and $\mathrm{KH}_{2} \mathrm{PO}_{4} 0.1 \%$, the $\mathrm{pH}$ being adjusted to 6.0. This potent strain was identified as Citeromyces sp. and showed highest removal efficiencies on stillage from an alcohol factory (U-MWW). The color intensity, chemical oxygen demand (COD) and biochemical oxygen demand (BOD) removal efficiencies were $75 \%$, almost 100 and 76\%, respectively. In a periodical feeding system, Citeromyces sp. WR-43-6 showed an almost constant decolorization yield of $60-70 \%$ over 8 days feeding of $10 \%$ fresh medium. In a replacement culture system, Citeromyces sp. WR-43-6 also gave a constant decolorization yield (about 75\%) during four times replacement. Yeast Citeromyces was used for treating MWW and high and stable removal efficiencies in both color intensity and organic matter were obtained.

Moriya et al. [118] used two flocculant strains of yeast, Hansenula fabianii and Hansenula anomala for treatment of wastewater from beet molasses-spirits production and achieved $25.9 \%$ and $28.5 \%$ removal of TOC respectively from wastewater without dilution. Dilution of wastewater was not favourable for practical treatment of wastewater due to the longer treatment time and higher energy cost. Shojaosadati et al. [119] optimized the growth conditions for single cell protein (SCP) production and COD reduction by the use of Hansenula sp. in sugar beet stillage. They concluded that production of SCP from stillage is one of the most promising options. Besides, the yeast was also found to utilize lactate and acetate that are inhibitory to ethanol production. As a result, the treated effluent could be used as dilution water for fermentation thereby reducing the residual stillage volume by $70 \%$.

\section{Role of enzymes in effluent decolorization}

The enzymatic treatment falls between the physicochemical and biological treatment processes. It has technological advantages and requires economical considerations to apply it on a large scale. It has some potential advantages over the conventional treatment. These includes: applicability to biorefractory compounds; operation either at high or low contaminant concentrations; operation over a wide range of $\mathrm{pH}$, temperature and salinity; absence of shock loading effects; absence of delays associated with the acclimatization of biomass; reduction in 
the sludge volume and the ease and simplicity of controlling the process [120]. Recent research has focused on the development of enzymatic processes for the treatment of wastewaters, solid wastes, hazardous wastes and soils in recognition of these potential advantages [121]. A large number of enzymes (e.g. peroxidases, oxidoreductases, cellulolytic enzymes cyanidase, proteases, amylases, etc.) from a variety of different sources have been reported to play an important role in an array of waste treatment applications [122-127].

Although the enzymatic system related with decolorization of melanoidins is yet to be completely understood, it seems greatly connected with fungal ligninolytic mechanisms. The white-rot fungi have a complex enzymatic system which is extracellular and non-specific, and under nutrient-limiting conditions is capable of degrading lignolytic compounds, melanoidins, and polyaromatic compounds that cannot be degraded by other microorganisms [102]. A large number of enzymes from a variety of different plants and microorganisms have been reported to play an important role in an array of waste treatment applications. Several studies regarding degradation of melanoidins, humic acids and related compounds using basidiomycetes have also suggested a participation of at least one laccase enzyme in fungi belonging to Trametes genus. The role of enzymes other than laccase or peroxidases in the decolorization of melanoidins by Trametes strain was reported during the 1980s. Several reports claimed that intracellular sugar-oxidase- type enzymes (sorbose- oxidase or glucose-oxidase) had melanoidin-decolorizing activities. It was suggested that melanoidins were decolorized by the active oxygen $\left(\mathrm{O}_{2} ; \mathrm{H}_{2} \mathrm{O}_{2}\right)$ produced by the reaction with sugar oxidases [128]. Decolorization by microbial methods includes the enzymatic breakdown of melanoidin and flocculation by microbially secreted substances. Ohmomo et al. [129] used C. versicolor Ps4a, which decolorized molasses wastewater $80 \%$ in darkness under optimum conditions. Decolorization activity involved two types of intracellular enzymes, sugar-dependent and sugar-independent. One of these enzymes required no sugar and oxygen for appearance of the activity and could decolorise MWW up to $20 \%$ in darkness and $11-17 \%$ of synthetic melanoidins. Thus, the participation of these $\mathrm{H}_{2} \mathrm{O}_{2}$ producing enzymes as a part of the complex enzymatic system for melanoidin degradation by fungi should be taken into account while designing any treatment strategy. One of the more complete enzymatic studies regarding melanoidin decolorization was reported by Miyata et al. [26]. Color removal of synthetic melanoidin by C. hirsutus involved the participation of peroxidases ( $\mathrm{MnP}$ and MIP) and the extracellular $\mathrm{H}_{2} \mathrm{O}_{2}$ produced by glucose-oxidase, without disregard of a partial participation of fungal laccase. The manganese peroxidase $(\mathrm{MnP})$ has also been reported in bacteria as extracellular enzyme for decolorization of melanoidin [72]. The involvement of $\mathrm{MnP}$ and laccase in white rot fungus for degradation of various biopolymers (lignin and tannin) has also been reported [130, 131]. But, the detail role of $\mathrm{MnP}$ and laccase in bacteria for decolorization of melanoidin has not been fully investigated.

Mansur et al. [132] obtained a maximum decolorization of around $60 \%$ on day 8 after inoculating with fungus Trametes sp. Here effluent was added at a final concentration of $20 \%(\mathrm{v} / \mathrm{v})$ after 5 days of fungal growth, the time at which high levels of laccase activity were detected in the extracellular mycelium. The white-rot basidiomycete T. versicolor is an active degrader of humic acids as well as of melanoidins. A melanoidin mineralizing $47 \mathrm{kDa}$ extracellular 
protein corresponding to the major mineralizing enzyme system from T. versicolor was isolated by Dehorter and Blondeau [133]. This $\mathrm{Mn}^{2+}$ dependent enzyme system required oxygen and was described to be as peroxidase. Uniform, small and spongy pellets of the fungus $T$. versicolor were used as inoculum for color removal using different nutrients such as ammonium nitrate, manganese phosphate, magnesium sulphate and potassium phosphate and also sucrose as carbon source [102]. Maximum color removal of $82 \%$ and $36 \%$ removal of $\mathrm{N}_{-} \mathrm{NH}_{4}$ was obtained on using low sucrose concentration and $\mathrm{KH}_{2} \mathrm{PO}_{4}$ as the only nutrient. Some studies have identified the lignin degradation related enzymes participating in the melanoidin decolorization. Intracellular $\mathrm{H}_{2} \mathrm{O}_{2}$ producing sugar oxidases have been isolated from Coriolus strains. Also, C. hirsustus have been reported to produce enzymes that catalyze melanoidin decolorization directly without additions of sugar and $\mathrm{O}_{2}$. Miyata et al. [26] used C. hirsutus pellets to decolorise a melanoidin-containing medium. It was elucidated that extracellular $\mathrm{H}_{2} \mathrm{O}_{2}$ and two extracellular peroxidases, a manganese-independent peroxidase (MIP) and manganese peroxidase $(\mathrm{MnP})$ were involved in decolorization activity. Lee et al. [134] investigated the dye-decolorizing peroxidase by cultivating Geotrichum candidum Dec1 using molasses as a carbon source. Components in the molasses medium stimulated the production of decolorizing peroxidase but inhibited the decolorizing activity of the purified enzyme. It was found that the inhibitory effect of molasses can be eliminated at dilution ratios of more than 25 . Recently D'souza et al. [135] reported $100 \%$ decolorization of $10 \%$ spent wash by a marine fungal isolate whose laccase production increased several folds in the presence of phenolic and non-phenolic inducers. A combined treatment technique consisting of enzyme catalyzed in situ transformation of pollutants followed by aerobic biological oxidation was investigated by Sangave and Pandit [121] for the treatment of alcohol distillery spent wash. It was suggested that enzymatic pretreatment of the distillery effluent leads to in situ formation of the hydrolysis products, which have different physical properties and are easier to assimilate than the parent pollutant molecules by the microorganisms, leading to faster initial rates of aerobic oxidation even at lower biomass levels. In another study, Sangave and Pandit [136] used irradiation and ultrasound combined with the use of an enzyme as pretreatment technique for treatment of distillery wastewater. The combination of the ultrasound and enzyme yielded the best COD removal efficiencies as compared to the processes when they were used as stand-alone treatment techniques. Enzymatic decolorization of molasses medium has also been tried using P. chrysosporium [111]. Under stationary cultivation conditions, none of the strains could decolorise molasses nor produce enzymes lignin peroxidase, manganese peroxidase and laccase. All of them could produce lignin peroxidase and manganese peroxidase when cultivated in flat bottom glass bottles under stationary cultivation conditions.

The $\mathrm{MnP}$ and laccase activity in the culture supernatant decreases with the increase in the time duration and further bacterial incubation showed gradual decrease of both enzyme activities. The enzyme activity has direct co-relation with the melanoidin decolorization. The initiation of $\mathrm{MnP}$ activity in culture supernatant starts at $48 \mathrm{~h}$ of bacterial growth and remains active up to $192 \mathrm{~h}$, whereas, the laccase induction starts at $96 \mathrm{~h}$ and its activity decreased after $192 \mathrm{~h}$. This resulted in the initial role of $\mathrm{MnP}$ in melanoidin degradation [70]. The melanoidin decolorization has also been reported by $\mathrm{MnP}$ activity in fungus $[8,108]$. The enzyme laccase also helps in decolorizing melanoidin [72, 137]. 
The white-rot basidiomycetous fungus $F$. flavus produces extracelluar enzymes, manganesedependent peroxidase (MNP), lignin peroxidase (LIP) and laccase which decolorizes a number of synthetic dyes like Poly $\mathrm{R}$ and remazol brilliant blue $\mathrm{R}$ etc. [138]. However, a negative correlation was found between $\mathrm{MnP}$ concentrations and decolorization of molasses spent wash (MSW) [139]. The levels of glucose oxidase activity also have correlation with decolorization of MSW. Raghukumar et al. [108] proposes that hydrogen peroxide produced as a result of glucose oxidase activity acts as a bleaching agent on MSW. Which has been further confirmed that in the absence of glucose the decolorization of MSW is lesser. With the addition of the starch to the medium, amylase activity stimulates and releasing reducing sugars. Which are oxidized by glucose oxidase producing hydrogen peroxide as a byproduct results in greater decolorization of MSW [108].

\section{Conclusion}

In the few last decades, interest has been developed in the field of bioremediation by using microbes. Several microorganisms such as bacteria and fungi, show a good ability to decolorize the effluent of the melanoidin based distillery industries. Thus, a better understanding of the microbial activities responsible for the degradation of melanoidins would contribute to enhancing the efficiency of the overall treatment system. In degradation process it would also be necessary to know the end product of melanoidins. Genetic improvement of isolates can be explored in future for improving their decolorization efficiency. Thus, it can be suggested that microbial decolorization holds promise and can be exploited to develop a cost effective, ecofriendly biotechnology package for the treatment of distillery effluent. More technically advanced research efforts are required for searching, exploiting new bacterial species and improvement of practical application to propagate the use of bacteria for bioremediation of industrial effluents. Enzymatic studies would be employed to understand the mechanism of degradation of melanoidins in future prospectives. Such organisms could be used in bioreactors for treatment of wastewaters or scaling up for enzyme productions. Broader validation of these new technologies and integration of different methods in the current treatment schemes will most likely in the near future, render these both efficient and economically viable. Finally, microbial bioremediation involves a combination of microbiologists, biotechnologists, chemists and engineers and is ideal to plug the ever widening gap between the different disciplines.

\section{Author details}

Anita Rani Santal ${ }^{1}$ and Nater Pal Singh ${ }^{2}$

1 Department of Microbiology, M. D. University, Rohtak, Haryana, India

2 Centre for Biotechnology, M. D. University, Rohtak, Haryana, India 


\section{References}

[1] Shweta, K. Current Trends in Bioremediation and Biodegradation. Journal of Bioremediation and Biodegradation (2012). e114.

[2] Asamudo, N. U, Daba, A. S, \& Ezeronye, O. U. Bioremediation of Textile Effluent Using Phanerochaete chrysosporium. African Journal of Food, Agriculture, Nutrition and Development (2011).

[3] Tyagi, M. da Fonseca MMR, de Carvalho CC. Bioaugmentation and Biostimulation Strategies to Improve the Effectiveness of Bioremediation Processes. Biodegradation (2011). , 22(2), 231-241.

[4] Madhavi, A, \& Rao, A. P. Effect of Industrial Effluent on Properties of Groundwater. Journal of Environmental Biology (2003). , 24(2), 187-192.

[5] Saravanamoorthy, M. D. Kumari BDR. Effect of Textile Wastewater on Morphophysiology and Yield on two Varieties of Peanut (Arachis hypogaea L.). Journal of Agricultural Technology (2007). , 3(2), 335-343.

[6] Naik, N. M, Jagdeesh, K. S, \& Alagawadi, A. R. Microbial Decolorization of Spentwash: A Review. Indian Journal of Microbiology (2008). , 48-41.

[7] Joshi, H. C. Bio-Energy Potential of Distillery Effluents. BioEnergy News (1999). , 3-10.

[8] Pant, D, \& Adholeya, A. Identification Ligninolytic Enzyme Activity and Decolorization Potential of two Fungi Isolated from a Distillery Effluent Contaminated Site. Water, Air and Soil Pollution (2007b). , 183-165.

[9] Chandra, R. Development of Microorganism for Removal of Color from Anaerobically Treated Distillery Effluent. Final technical report submitted to Department of Biotechnology New Delhi; (2003).

[10] Chandra, R, Kumar, K, \& Singh, J. Impact of Anaerobically Treated and Untreated (Raw) Distillery Effluent Irrigation on Soil Microflora Growth Total Chlorophyll and Protein Contents of Phaseolus aureus L. Journal of Environmental Biology (2004). , 25(4), 381-385.

[11] Pazouki, M, Shayegan, J, \& Afshari, A. Screening of Microorganisms for Decolorization of Treated Distillery Wastewater. Iranian Journal of Science and Technology (2008). , 32-53.

[12] FitzGibbon FSingh D, McMullan G, Marchant R. The Effect of Phenolic Acids and Molasses Spent Wash Concentration on Distillery Wastewater Remediation by Fungi. Process Biochemistry (1998). , 33(8), 799-803.

[13] Pant, D, \& Adholeya, A. Biological Approaches for Treatment of Distillery Wastewater: A Review. Bioresource Technology (2007a). , 98-2321. 
[14] Chandra, R, Bharagava, R. N, \& Rai, V. Melanoidins as Major Colorant in Sugarcane Molasses Based Distillery Effluent and its Degradation. Bioresource Technology (2008). , 99-4648.

[15] Mohana, S, Desai, C, \& Madamwar, D. Biodegradation and Decolorization of Anaerobically Treated Distillery Spent Wash by a Novel Bacterial Consortium. Bioresource Technology (2007). , 98(2), 333-339.

[16] Kumar, P, \& Chandra, P. Decolorization and Detoxification of Synthetic Molasses Melanoidins by Individual and Mixed Cultures of Bacillus spp. Bioresource Technology (2006). , 97-2096.

[17] Wedzicha, B. L, \& Kaputo, M. T. Melanoidins from Glucose and Glycine: Composition, Characteristics and Reactivity towards Sulphite Ion. Food Chemistry (1992). , 43-359.

[18] Reynolds, T. M. Chemistry of Non-Enzymatic Browning of the Reaction Between Aldoses and Amines. Advances in Food Research (1968). , 12-1.

[19] Kumar, V, \& Wati, L. FitzGibbon FJ, Nigam P, Banat IM, Singh D, Marchant R. Bioremediation and Decolorization of Anaerobically Digested Distillery Spent Wash. Biotechnology Letters (1997a). , 19(4), 311-313.

[20] Kumar, V, Wati, L, Nigam, P, \& Banat, I. M. MacMullan G, Singh D, Marchant R. Microbial Decolorization and Bioremediation of Anaerobically Digested Molasses Spent Wash Effluent by Aerobic Bacterial Culture. Microbios (1997b). , 89-81.

[21] Kim, S. B, Hayase, F, \& Kato, H. Decolorization and Degradation Products of Melanoidins on Ozonolysis. Agricultural and Biological Chemistry (1985). , 49(3), 785-792.

[22] Ohmomo, S, Kaneko, Y, Sirianuntapiboon, S, Somachi, P, Atthasumpunna, P, \& Nakamura, I. Decolorization of Molasses Wastewater by a Thermophilic Strain Aspergillus fumigatus G- Agricultural and Biological Chemistry (1987). , 2-6.

[23] Satyawali, Y, \& Balakrishnan, M. Removal of Color from Biomethanated Distillery Spentwash by Treatment with Activated Carbons. Bioresource Technology (2007). , 98-2629.

[24] Ivarson, K. C, \& Benzing-purdie, L. M. Degradation of Melanoidins by Soil Microorganisms Under Laboratory Conditions. Canadian Journal of Soil Science (1987). , 67-409.

[25] Kitts, D. D, Wu, C. H, Stich, H. F, \& Powrie, W. D. Effect of Glucose-Lysine Maillard Reaction Products on Bacterial and Mammalian Cell Mutagenesis. Journal of Agriculture and Food Chemistry (1993). , 41(12), 2353-2358.

[26] Miyata, N, Iwahori, K, \& Fujita, M. Manganese-Independent and-Dependent Decolorization of Melanoidin by Extracellular Hydrogen Peroxide and Peroxidases from 
Coriolus hirsutus pellets. Journal of Fermentation and Bioengineering (1998). , 85(5), 550-553.

[27] Silvan, J. M. Lagemaat JVD, Olano A, Castillo MDD. Analysis and Biological Properties of Amino Acid Derivates Formed by Maillard Reaction in Foods. Journal of Pharmaceutical and Biomedical Analysis (2006). , 41-1543.

[28] Morales, F, \& Jimnez-perez, S. Free Radical Scavenging Capacity of Maillard Reaction Products as Related to Color and Fluorescence. Food Chemistry (2001). , 72-119.

[29] Cammerer, B, Jaluschkov, V, \& Kroh, L. W. Carbohydrates structures as part of the melanoidins skeleton. International Congress Series (2002). , 1245-269.

[30] Manisankar, P, Rani, C, \& Vishwanathan, S. Effect of Halides in the Electrochemical Treatment of Distillery Effluent. Chemosphere (2004). , 57-961.

[31] Sirianuntapiboon, S, Zohsalam, P, \& Ohmomo, S. Decolorization of Molasses Wastewater by Citeromyces spWR- Process Biochemistry (2004a). , 43-6.

[32] Migo, V. P. Del Rosario EJ, Matsumura M. Flocculation of Melanoidins Induced by Inorganic Ions. Journal of Fermentation and Bioengineering (1997). , 83(3), 287-291.

[33] Miura, M, \& Gomyo, T. Formation of Blue Pigments in the Earlier Stage of Browning in the System Composed of D-Xylose and Glycine. Nippon Nogeikagaku Kaishi (1982). , 56-417.

[34] Hayase, F, Takahashi, Y, Tominaga, S, Miura, M, Gomyo, T, \& Kato, H. Identification of Blue Pigment Formed in a D-Xylose-Glycine Reaction System. Bioscience, Biotechnology, and Biochemistry (1999). , 63(8), 1512-1514.

[35] Hodge, J. E. Chemistry of Browning Reactions in Model Systems. Journal of Agriculture and Food Chemistry (1953). , 1-928.

[36] Hayashi, T, \& Namiki, M. Role of Sugar Fragmentation in an Early Stage Browning of Amino-Carbonyl Reaction of Sugar with Amino Acid. Agricultural and Biological Chemistry (1986). , 50(8), 1965-1970.

[37] Sowmeyan, R, \& Swaminathan, G. Effluent Treatment Process in Molasses Based Distillery Industries: A Review. Journal of Hazardous Materials (2008). , 152-453.

[38] Venkat, S. M, Krishna, S. M, \& Karthikeyan, J. Adsorption Mechanism of Acid-Azo Dye from Aqueous Solution on to Coal/Coal Based Sorbents and Activated Carbon: A Mechanist Study. In: Jayarama Reddy S. (ed.) Analytical Techniques in Monitoring the Environment. Tirupathi, India: Student offset printers; (2000). , 97-103.

[39] Bernardo, E. C, Egashira, R, \& Kawasaki, J. Decolorization of Molasses Wastewater Using Activated Carbon Prepared from Cane Bagasses. Carbon (1997). , 35(9), 1217-1221. 
[40] Satyawali, Y, \& Balakrishnan, M. Wastewater Treatment in Molasses-Based Alcohol Distilleries for Cod and Color Removal: A Review. Journal of Environmental Management (2008). , 86-481.

[41] Bitton, G, Jung, K, \& Koopman, B. Evaluation of a Microplate Assay Specific for Heavy Metal Toxicity. Archives of Environmental Contamination and Toxicology (1994). , 27(1), 25-28.

[42] Pandey, R. A, Malhotra, S, Tankhiwale, A, Pande, S, Pathe, P. P, \& Kaul, S. N. Treatment of Biologically Treated Distillery Effluent- A Case Study. International Journal of Environmental Studies (2003). , 60(3), 263-275.

[43] Migo, V. P, Matsumura, M, Delrosario, E. J, \& Kataoka, H. Decolorization of Molasses Wastewater Using an Inorganic Flocculent. Journal of Fermentation and Bioengineering (1993). , 75-438.

[44] Coca, M, Pena, M, \& Gonzalez, G. Chemical Oxidation Processes for Decolorization of Brown Colored Molasses Wastewater. Ozone: Science and Engineering (2005). , 27-365.

[45] Kumaresan, T. Sheriffa Begum KMM, Sivashanmugam P, Anantharaman N, Sundaram S. Experimental Studies on Treatment of Distillery Effluent by Liquid Membrane Extraction. Chemical Engineering Journal (2003).

[46] De Wilde FGNDemineralization of a Molasses Distillery Wastewater. Desalination (1987). , 67-481.

[47] Bories, A, Sire, Y, \& Colin, T. Odorous Compounds Treatment of Winery and Distillery Effluents During Natural Evaporation in Ponds. Water Science and Technology (2005). , 51(1), 129-136.

[48] Bhandari, H. C, Mitra, A. K, \& Kumar, S. Crest's Integrated System: Reduction and Recycling of Effluents in Distilleries. In: Tewari P.K. (ed.) Liquid Asset Proceedings of Indo-EU Workshop on Promoting Efficient Water Use in Agro-based Industries. New Delhi, India: TERI Press; , 167-169.

[49] Gulati, N. Conservation of Resources Using Evaporation and Spray Drying Technology for Distillery and Paper Industries. In: Tewari P.K. (ed.) Liquid Asset Proceedings of Indo-EU Workshop on Promoting Efficient Water Use in Agro-Based Industries. New Delhi, India: TERI Press; (2004). , 163-166.

[50] Cortez LABPerez LEB. Experiences on Vinasse Disposalpart III: Combustion of Vinasse Fuel Oil Emulsions. Brazilian Journal of Chemical Engineering (1997). , 14(1), 9-18.

[51] Joshi, D. L. High Rate Anaerobic Treatment of Industrial Wastewater in Tropics. Thammasat International Journal of Science and Technology (1998). , 3(1), 1-7. 
[52] Nandy, T, Shastry, S, \& Kaul, S. N. Wastewater Management in a Cane Molasses Distillery Involving Bioresource Recovery. Journal of Environmental Management (2002). , 65-25.

[53] Bhoi ZMPMehrotra I, Shrivastava AK. Treatability Studies of Black Liquor by Upflow Anaerobic Sludge Blanket Reactor. Journal of Environmental Engineering and Science (2003). , 2(4), 307-331.

[54] Farhadian, M, Borghei, M, \& Umrania, V. V. Treatment of Beet Sugar Wastewater by UAFB Bioprocess. Bioresource Technology (2007). , 98-3080.

[55] Travieso, L, Sánchez, E, Borja, R, Benítez, F, Raposo, F, Rincón, B, \& Jiménez, A. M. Evaluation of a Laboratory-Scale Stabilization Pond for Tertiary Treatment of Distillery Waste Previously Treated by a Combined Anaerobic Filter-Aerobic Trickling System. EcolEngg (2006). , 27(2), 100-108.

[56] Sharma, J, \& Singh, R. Effect of Nutrients Supplementation on Anaerobic Sludge Development and Activity for Treating Distillery Effluent. Bioresource Technology (2001). , 79-203.

[57] Driessen WJBMTielbaard MH, Vereijken TLFM. Experience on Anaerobic Treatment of Distillery Effluent with the UASB Process. Water Science and Technology (1994). , 30(12), 193-201.

[58] Blonskaja, V, Menert, A, \& Vilu, R. Use of Two-Stage Anaerobic Treatment for Distillery Waste. Advances in Environmental Research (2003). , 7(3), 671-678.

[59] Beltran, F. J, Garcia-araya, J. F, \& Alvarez, P. M. Wine Distillery Wastewater Degradation Improvement of Aerobic Biodegradation by Means of an Integrated Chemical (Ozone)-Biological Treatment. Journal of Agricultural and Food Chemistry (1999). , 47-3919.

[60] Kitamura, Y, Maekawa, T, Tagawa, A, Hayashi, H, \& Farrell-poe, K. L. Treatment of Strong Organic Nitrogenous Wastewater by an Anaerobic Contact Process Incorporating Ultrafiltration. Applied Engineering in Agriculture (1996). , 12-709.

[61] Yeoh, B. G. Two-Phase Anaerobic Treatment of Cane-Molasses Alcohol Stillage. Water Science and Technology (1997). , 36-441.

[62] Harada, H, Uemura, S, Chen, A. C, \& Jayadevan, J. Anaerobic Treatment of a Recalcitrant Distillery Wastewater by a Thermophilic UASB Reactor. Bioresource Technology (1996). , 55(3), 215-221.

[63] Bhatti, Z. I, Furukawa, K, \& Fujita, M. Microbial Diversity in UASB Reactors. Pure and Applied Chemistry (1997). , 69(11), 2431-2438.

[64] Babu, V. L, Mohan, S. V, \& Sharma, P. N. Influence of Reactor Configuration on Fermentative Hydrogen Production During Wastewater Treatment. International Journal of Hydrogen Energy (2009). , 34(8), 3305-3312. 
[65] Bhatia, D, Vieth, W. R, \& Vekatasubramanian, K. Steady State and Transit Behaviour in Microbial Methanification: II. Mathematical Modeling and Verification. Biotechnology and Bioengineering (1985). , 27(8), 1192-1198.

[66] Parkin, G. F, \& Speece, R. E. Yang CHJ, Kocher WM. Response of Methane Formation Systems to Industrial Toxicants. Journal of the Water Pollution Control Federation (1983). , 55-44.

[67] Karhadkar, P. P, Handa, B. K, \& Khanna, P. Pilot-Scale Distillery Spent Wash Biomethanation. Journal of Environmental Engineering (1990). , 116(6), 1029-1045.

[68] Krzywonos, M, \& Seruga, P. Decolorization of Sugar Beet Molasses Vinasse a High Strength Distillery Wastewater by Lactic Acid Bacteria. Polish Journal of Environmental Studies (2012). , 21(4), 943-948.

[69] Krzywonos, M. Decolorization of Sugar Beet Distillery Effluent Using Mixed Cultures of Bacteria of the Genus Bacillus. African Journal of Biotechnology (2012). , 11(14), 3464-3475.

[70] Yadav, S, \& Chandra, R. Biodegradation of Organic Compounds of Molasses Melanoidin (MM) from Biomethanated Distillery Spent Wash (BMDS) during the Decolorization by a Potential Bacterial Consortium. Biodegradation (2012). , 23-609.

[71] Santal, A. R, Singh, N. P, \& Saharan, B. S. Biodegradation and Detoxification of Melanoidin from Distillery Effluent Using an Aerobic Bacterial Strain $\mathrm{SAG}_{5}$ of Alcaligenes faecalis. Journal of Hazardous Materials (2011). , 193-319.

[72] Bharagava, R. N, Chandra, R, \& Rai, V. Isolation and Characterization of Aerobic Bacteria Capable of the Degradation of Synthetic and Natural Melanoidins from Distillery Effluent. World Journal of Microbiology and Biotechnology (2009). , 25-737.

[73] Tondee, T, \& Sirianuntapiboon, S. Decolorization of Molasses Wastewater by Lactobacillus plantarum NoPV Bioresource Technology (2008). , 71-1861.

[74] Jiranuntipon, S, Chareonpornwattana, S, Damronglerd, S, Albasi, C, \& Delia, M. L. Decolorization of Synthetic Melanoidins-Containing Wastewater by a Bacterial Consortium. Journal of Industrial Microbiology and Biotechnology (2008). , 35-1313.

[75] Adikane, H. V, Dange, M. N, \& Selvakumari, K. Optimization of Anaerobically Digested Distillery Molasses Spent Wash Decolorization Using Soil as Inoculum in the Absence of Additional Carbon and Nitrogen Source. Bioresourse Technology (2006). , 97-2131.

[76] Sivakumar, N, Saravanan, V, \& Balakumar, S. Bacterial Decolorization and Bioremediation of an Anaerobically Digested Molasses Spent Wash. Asian Journal of Microbiology, Biotechnology and Environment Science (2006). , 8(2), 291-295. 
[77] Chavan, M. N, Kulkarni, M. V, Zope, V. P, \& Mahulikar, P. P. Microbial Degradation of Melanoidins in Distillery Spent Wash by an Indigenous Isolate. Indian Journal of Biotechnology (2006). , 5-416.

[78] Ghosh, M, Verma, S. C, Mengoni, A, \& Tripathi, A. K. Enrichment and Identification of Bacteria Capable of Reducing Chemical Oxygen Demand of Anaerobically Treated Molasses Spent Wash. Journal of Applied Microbiology (2004). , 96-1278.

[79] Sirianuntapiboon, S, Phothilangka, P, \& Ohmomo, S. Decolorization of Molasses Wastewater by a Strain of Acetogenic Bacteria. Bioresource Technology (2004b). (BP103), 92-31.

[80] Cibis, E, Kent, C. A, Krzywonos, M, Garncarek, Z, Garncarek, B, \& Miskiewicz, T. Biodegradation of Potato Slops from a Rural Distillery by Thermophilic Aerobic Bacteria. Bioresource Technology (2002). , 85-57.

[81] Savant, D. V, Shouche, Y. S, Prakash, S, \& Ranade, D. R. Methanobrevibacter acididurans sp. nov a Novel Methanogen from a Sour Anaerobic Digester. International Journal of Systematic and Evolutionary Microbiology (2002). , 52-1081.

[82] Ghosh, M, Ganguli, A, \& Tripathi, A. K. Treatment of Anaerobically Digested Distillery Spentwash in a Two-Stage Bioreactor Using Pseudomonas putida and Aeromonas sp. Process Biochemistry (2002). , 37(8), 857-862.

[83] Dahiya, J, Singh, D, \& Nigam, P. Decolorization of Molasses Wastewater by Cells of Pseudomonas fluorescens Immobilized on Porous Cellulose Carrier. Bioresource Technology (2001b). , 78-111.

[84] Jain, N, Minocha, A. K, \& Verma, C. L. Degradation of Predigested Distillery Effluent by Isolated Bacterial Strains. Indian Journal of Experimental Botany (2002). , 40-101.

[85] Masaharu, S, Hiromi, K, Akihiro, N, Naoshi, F, \& Rikiya, T. Screening and Identification of Lactic Acid Bacteria with the Ability to Decolorize Wastewater from a Molasses Alcohol Distillery. Journal of the Brewing Society of Japan (1998). , 93(12), 982-989.

[86] Kambe, T. N, Shimomura, M, Nomura, N, Chanpornpong, T, \& Nakahara, T. Decolorization of Molasses Wastewater by Bacillus Spunder Thermophilic and Anaerobic Conditions. Journal of Bioscience and Bioengineering (1999). , 87(1), 119-121.

[87] Sirianuntapiboon, S. Selection of Acid Forming Bacteria Having Decolorization Activity for Removal of Color Substances from Molasses Wastewater. Thammasat International Journal of Science and Technology (1999). , 4(2), 1-12.

[88] Ohmomo, S, Daengsabha, W, Yoshikawa, H, Yui, M, Nozaki, K, Nakajima, T, \& Nakamura, I. Screening of Anaerobic Bacteria with the Ability to Decolorize Molasses Melanoidin. Agricultural and Biological Chemistry (1988a). , 57-2429.

[89] Kumar, V, Wati, L, Nigam, P, Banat, I. M, Yadav, B. S, Singh, D, \& Marchant, R. Decolorization and Biodegradation of Anaerobic Digested Sugarcane Molasses Spent- 
wash Effluent from Biomethanation Plants by White Rot Fungi. Process Biochemistry (1998). , 33(1), 83-88.

[90] Miranda, P. M, Benito, G. G, Cristobal, N. S, \& Nieto, C. H. Color Elimination from Molasses Wastewater by Aspergillus niger. Bioresource Technology (1996). , 57-229.

[91] Angayarkanni, J, Palaniswamy, M, \& Sawminathan, K. Biotreatment of Distillery Effluent Using Aspergillus niveus. Bulletin of Environmental Contamination and Toxicology (2003). , 70-268.

[92] Shayegan, J, Pazouki, M, \& Afshari, A. Continuous Decolorization of Anaerobically Digested Distillery Wastewater. Process Biochemistry (2004). , 40-1323.

[93] Guimaraes, C. Bento LSM, Mota M. Biodegradation of Colorants in Refinery Effluents-Potential Use of the Fungus Phanerochaete chrysosporium. International Sugar Journal (1999). , 101-246.

[94] Ohmomo, S, Itoh, N, Watanabe, Y, Kaneko, Y, Tozawa, Y, \& Ueda, K. Continuous Decolorization of Molasses Wastewater with Mycelia of Coriolus versicolor Ps4a. Agricultural and Biological Chemistry (1985b). , 49-2551.

[95] Ohmomo, S, Kainuma, M, Kamimura, K, Sirianuntapiboon, S, Oshima, I, \& Atthasumpunna, P. Adsorption of Melanoidin to the Mycelia of Aspergillus oryzae Y- Agricultural and Biological Chemistry (1988b). , 2-32.

[96] Borja, R, Martin, A. M, \& Duran, M. M. Enhancement of the Anaerobic Digestion of Wine Distillery Wastewater by the Removal of Phenolics Inhibitors. Bioresource Technology (1993). , 45-99.

[97] Sirianuntapiboon, S, Sihanonth, P, Somachai, P, Atthasampunna, P, \& Hayashida, S. An Adsorption Mechanism for Melanoidins Decolorization by Rhizoctonia sp. Bioscience, Biotechnology, and Biochemistry (1995). , 59-1185.

[98] Murata, M, Terasawa, N, \& Homma, S. Screening of Microorganisms to Decolorize a Model Melanoidin and the Chemical Properties of a Microbially Treated Melanoidin. Bioscience, Biotechnology, and Biochemistry (1992). , 56(8), 1182-1187.

[99] Kida, K, Morimura, S, Abe, N, \& Sonoda, Y. Biological Treatment of Shochu Distillery Wastewater. Process Biochemistry (1995). , 30(2), 125-132.

[100] Fujita, M, Era, A, Ike, M, Soda, S, Miyata, N, \& Hirao, T. Decolorization of HeatTreatment Liquor of Waste Sludge by a Bioreactor Using Polyurethane Foam-Immobilized White Rot Fungus Equipped with an Ultramembrane Filtration Unit. Journal of Bioscience Bioengineering (2000). , 90(4), 387-94.

[101] Fumi, M. D, Parodi, G, Parodi, E, \& Silva, A. Optimisation of Long Term Activated Sludge Treatment of Winery Wastewater. Bioresource Technology (1995). , 52(1), 45-51. 
[102] Benito, G. G, Miranda, M. P, \& Santos, D. R. Decolorization of Wastewater from an Alcoholic Fermentation Process with Trametes Versicolor. Bioresource Technology (1997). , 61-33.

[103] Sirianuntapiboon, S, \& Chairattanawan, K. Some Properties of Coriolus sp. No.20 for Removal of Color Substances from Molasses Wastewater. Thammasat International Journal of Science and Technology (1998). , 3(2), 74-79.

[104] Miyata, N, Mori, T, Iwahori, K, \& Fujita, M. Microbial Decolorization of MelanoidinContaining Wastewaters: Combined Use of Activated Sludge and the Fungus Coriolus hirsutus. Journal of Bioscience and Bioengineering (2000). , 89(2), 145-150.

[105] Dahiya, J, Singh, D, \& Nigam, P. Decolorization of Synthetic and Spentwash Melanoidins Using the White-Rot Fungus Phanerochaete chrysosporium JAG-40. Bioresource Technology (2001a). , 78-95.

[106] Malandra, L, Wolfaardt, G, Zietsman, A, \& Viljoen-bloom, M. Microbiology of a Biological Contractor for Winery Wastewater Treatment. Water Research (2003). , 37-4125.

[107] Kwak, E. J, Lee, Y. S, Murata, M, \& Homma, S. Effect of Reaction pH on the Photodegradation of Model Melanoidins. Lebensmittel-Wissenschaft und-Technologie (2004). , 37-255.

[108] Raghukumar, C, Mohandass, C, Kamat, S, \& Shailaja, M. S. Simultaneous Detoxification and Decolorization of Molasses Spent Wash by the Immobilized White-Rot Fungus Flavodon flavus Isolated from a Marine Habitat. Enzyme and Microbial Technology (2004). , 35-197.

[109] Raghukumar, C, \& Rivonkar, G. Decolorization of Molasses Spent Wash by the White-Rot Fungus Flavodon flavus Isolated from a Marine Habitat. Applied Microbiology and Biotechnology (2001). , 55-510.

[110] Potentini, M. F, \& Rodríguez-malaver, A. J. Vinasse Biodegradation by Phanerochaete chrysosporium. Journal of Environmental Biology (2006). , 27(4), 661-665.

[111] Thakkar, A. P, Dhamankar, V. S, \& Kapadnis, B. P. Biocatalytic Decolorization of Molasses by Phanerochaete chrysosporium. Bioresource Technology (2006). , 97-1377.

[112] Sirianuntapiboon, S, Somachi, P, \& Sihanonth, P. Ohmomo PAS. Microbial Decolorization of Molasses Wastewater by Mycelia Sterilia D90. Agricultural and Biological Chemistry (1988). , 52(2), 393-398.

[113] Seyis, I, \& Subasioglu, T. Screening of Different Fungi for Decolorization of Molasses. Brazilian Journal of Microbiology (2009). , 40-61.

[114] Kaushik, G, \& Thakur, I. S. Isolation of Fungi and Optimization of Process Parameters for Decolorization of Distillery Mill Effluent. World Journal of Microbiology and Biotechnology (2009). , 25-955. 
[115] Valderrama, L. T. Del Campo CM, Rodriguez CM, Bashan LE, Bashan Y. Treatment of Recalcitrant Wastewater from Ethanol and Citric Acid Using the Microalga Chlorella vulgaris and the Macrophyte Lemna minuscule. Water Research (2002). , 36-4185.

[116] Kalavathi, D. F, Uma, L, \& Subramanian, G. Degradation and Metabolization of the Pigment-Melanoidin in Distillery Effluent by the Marine Cyanobacterium Oscillatoria boryana BDU 92181. Enzyme and Microbial Technology (2001). , 29-246.

[117] Patel, A, Pawar, P, Mishra, S, \& Tewari, A. Exploitation of Marine Cyanobacteria for Removal of Color from Distillery Effluent. Indian Journal of Environmental Protection (2001). , 21-1118.

[118] Moriya, K, Lefuji, H, Shimoi, H, Sato, S, \& Tadenuma, M. Treatment of Distillery Wastewater Discharged from Beet Molasses-Spirits Production Using Yeast. Journal of Fermentation and Bioengineering (1990). , 69-138.

[119] Shojaosadati, S. A, Khalilzadeh, R, Jalilzadeh, A, \& Sanaei, H. R. Bioconversion of Molasses Stillage to Protein as an Economic Treatment of this Effluent. Resources, Conservation and Recycling (1999).

[120] Karam, J, \& Nicell, J. A. Potenital Applications of Enzymes in Waste Treatment. Journal of Chemical Technology and Biotechnology (1997). , 69-141.

[121] Sangave, P. C, \& Pandit, A. B. Enhancement in Biodegradability of Distillery Wastewater Using Enzymatic Pretreatment. Journal of Environmental Management (2006a). , 78-77.

[122] Klibanov, A. M, Alberti, B. N, Morris, E. D, \& Felshin, L. M. Enzymatic Removal of Toxic Phenols and Anilines from Wastewaters. Journal of Applied Biochemistry (1980). , 2-414.

[123] Klibanov, A. M, \& Morris, E. D. Horseradish Peroxidases for the Removal of Carcinogenic Aromatic Amines from Water. Enzyme and Microbial Technology (1981). , 3-119.

[124] Aitken, M. D, \& Irvine, R. L. Stability Testing of Ligninase and Mnperoxidase from Phanerochaete Chrysosporium. Biotechnology and Bioengineering (1989). , 34(10), 1251-1260.

[125] Duff, S. J, Moritz, J. W, \& Andersen, K. L. Simultaneous Hydrolysis and Fermentation of Pulp Mill Primary Clarifier Sludge. Canadian Journal of Chemical Engineering (1994). , 72-1013.

[126] Ferrer, I, Dezotti, M, \& Duran, N. Decolorization of Kraft Effluent by Free and Immobilized Lignin Peroxidases and Horse Radish Peroxidases. Biotechnology Letters (1991). , 13-577.

[127] Dec, J, \& Bollag, J. M. Use of Plant Material for the Decontamination of Water Polluted with Phenols. Biotechnology and Bioengineering (1994). , 44-1132. 
[128] Watanabe, Y, Sugi, R, \& Tanaka, Y. Enzymatic Decolorization of Melanoidin by Coriolus sp. No 20. Agricultural and Biological Chemistry (1982). , 46(6), 1623-1630.

[129] Ohmomo, S, Aoshima, I, Tozawa, Y, Sakurada, N, \& Ueda, K. Purification and Some Properties of Melanoidin Decolorizing Enzymes and P-4 from Mycelia of Coriolus versicolor Ps4a. Agricultural and Biological Chemistry (1985a). , 3.

[130] Arora, D. S, Chander, M, \& Gill, P. K. Involvement of Lignin Peroxidase, Manganese Peroxidase and Laccase in Degradation and Selective Ligninolysis of Wheat Straw. International Biodeterioration and Biodegradation (2002). , 50-115.

[131] Rubia TDLLinares A, Perez J, Dorado JM, Romera J, Martinez J. Characterization of Manganese-Dependent Peroxidase Isoenzymes from the Ligninilytic Fungus Phanerochaete flavido-alba. Research in Microbiology (2002). , 153-547.

[132] Mansur, M, Suarez, T, \& Fernandez-larrea, J. B. Brizuela MAA, Gonzalezi AE. Identification of a Laccase Gene Family in the New Lignin-Degrading Basidiomycetes CECT 20197. Applied and Environmental Microbiology (1997). , 63(7), 2637-2646.

[133] Dehorter, B, \& Blondeau, R. Isolation of an Extracellular Mn-Dependent Enzyme Mineralizing Melanoidins from the White Rot Fungus Trametes versicolor. FEMS Microbiology Letters (1993). , 109(1), 117-122.

[134] Lee, T. H, Aoki, H, Sugano, Y, \& Shoda, M. Effect of Molasses on the Production and Activity of Dye-Decolorizing Peroxidase from Geotrichum candidum. Journal of Bioscience and Bioengineering (2000). , 89-545.

[135] Souza, D, Tiwari, D. T, Sah, R, \& Raghukumar, A. K. C. Enhanced Production of Laccase by a Marine Fungus During Treatment of Colored Effluents and Synthetic Dyes. Enzyme and Microbial Technology (2006). , 38-504.

[136] Sangave, P. C, \& Pandit, A. B. Ultrasound and Enzyme Assisted Biodegradation of Distillery Wastewater. Journal of Environmental Management (2006b). , 80-36.

[137] Yadav, S, Chandra, R, \& Rai, V. Characterization of Potential MnP Producing Bacteria and its Metabolic Products During Decolorization of Synthetic Melanoidins due to Biostimulatory Effect of D-Xylose at Stationary Phase. Process Biochemistry (2011). , 86-1774.

[138] Raghukumar, C, Souza, D, Thorn, T. M, Reddy, R. G, \& Lignin-modifying, C. A. Enzymes of Flavodon flavus a Basidiomycete isolated from a Coastal Marine Environment. Applied Environmental Microbiology (1999). , 65-2103.

[139] Raghukumar, C. Fungi from Marine Habitat: Application in Bioremediation. Mycological Research (2000). , 104-1222. 